\title{
The timing of new corporate debt issues and the risk-return tradeoff
}

\author{
Dimitrios Koutmos* \\ Worcester Polytechnic Institute, United States \\ Konstantinos Bozos \\ University of Leeds, United Kingdom \\ CIBER, Georgia State University, United States \\ Dionysia Dionysiou \\ University of Stirling, United Kingdom \\ Neophytos Lambertides \\ Cyprus University of Technology, Cyprus
}

REVISED MANUSCRIPT: June 2017

REVIEW OF QUANTITATIVE FINANCE AND ACCOUNTING

Accepted for publication in Review of Quantitative Finance and Accounting published by Springer.

* Address correspondence to Dimitrios Koutmos electronically via dkoutmos@WPI.edu or post at the following address: 100 Institute Road, Worcester, MA 01609, USA. 


\begin{abstract}
The Modigliani-Miller theorem serves as the standard finance paradigm on corporate capital structure and managerial decision making. Implicitly, it is assumed that the market possesses full information about the firm. However, if firm managers have insider information, they may attempt to 'signal' changes in the firm's financial structure and, in competitive equilibrium, shareholders will draw deductions from such signals. Empirical work shows that the value of underlying firms rises with leverage because investors expect such firms to implement positive NPV projects. We empirically examine this view using a sample of debt issue announcements by publicly traded firms listed on the London Stock Exchange. We argue that the timing of debt issues is fundamental in determining the relationship between leverage and riskadjusted returns. We show that an announcing firm's intrinsic value may not rise depending on when management publicly 'signals' changes in their firm's capital structure. Specifically, we show that riskadjusted returns rise positively for firms that make debt announcements during normal economic conditions while they tend to decline for firms making debt announcements during recessionary periods. During recessionary periods, market risk and loss aversion rise and investors focus less on the potential growth of debt announcing firms and focus more on potential losses instead. We conclude that the timing of new debt is of paramount importance and managers' inability to prudently time such announcements can lead to exacerbated levels of systematic risk coupled with a significant erosion in shareholder wealth.
\end{abstract}

Keywords: Debt announcements; risk-return tradeoff; Modigliani-Miller; bivariate EGARCH. IEL classification: G12; G14; G30; G32 


\section{INTRODUCTION}

Debt announcements provide rich information to investors and other stakeholders. In the context of the Modigliani-Miller theorem on the irrelevancy of capital structure on firm valuation, outside investors and inside managers have access to the same information regarding the firm's current earnings and its future investment opportunity set. If, however, inside managers possess more information than outside investors, then there exists a degree of information asymmetry. Such information asymmetry can increase or decrease stochastically across time and, as we show here, is linked to the general mood in the market and economic conditions at large. In fact, it is not uncommon for inside managers to use various corporate announcements as a means of 'signalling' to the market with the aim to reduce information asymmetries. For example, a firm may announce unexpectedly large dividends, especially during hard economic times, in order to signal that it is in strong financial health. In a similar vein, managers may use debt announcements as a tool to signal to investors that their firm is seeking out positive net present value (NPV) projects that can enhance the total value of the firm.

Given the barrier of information asymmetry separating inside managers from outside investors (e.g., Akerlof, 1970), the overriding question is, are debt announcements construed as a positive or negative signal by investors? This question is not easy to answer given the multiple layers of competing benefits and costs linked with debt announcements, including tax shield benefits, investment opportunities that can be pursued, costs incurred by augmenting financial distress measures and agency costs arising due to conflicting interests between bondholders and stockholders.

Theoretical predictions as to how markets construe debt announcements have been mixed ever since the Modigliani and Miller (1958) theorem on the irrelevancy of firm capital structure on price valuation. Miller (1977) shows that this proposition ought to hold in the presence of taxes. Ross (1977) posits a signalling model whereby rises in leverage are linked with rises in the market's perception of the underlying firm's value, due to the fact that inside managers possess more complete information about their firm's growth opportunities than do outside investors. ${ }^{1}$ Debt announcements can serve to mitigate this information asymmetry and can be used to signal managerial optimism regarding their firm's investment opportunity set and earnings prospects. From an empirical perspective, there are two inextricable parameters of interest that can be dissected from the time series of the announcing firms' stock price data, which help answer the question of whether debt announcements send a positive or negative signal: the respective underlying firms' risk and returns. As discussed at greater length in the second section of this paper, the literature is focused almost exclusively on ensuing returns following debt announcements. The universal methodological treatment applied stems from the single-period CAPM or some market-model variant and utilizes abnormal returns (AR) or cumulative

\footnotetext{
${ }^{1}$ Ross $(1973 ; 1977)$ posits a model whereby leverage signals firm quality and the presence of positive NPV projects. According to Ross, firms of high quality have the ability to meet their periodic interest payments throughout the life of their bonds. Thus, they are more apt at raising funds in order to invest in positive NPV projects which will enhance future earnings. On the flip side, firms of low quality do not have the capacity to sustain such interest payments.
} 
abnormal returns (CAR) in order to draw inferences as to what happens to shareholder wealth before and after a debt announcement.

For reasons which we build upon more analytically later on in this paper, we argue that single period AR approaches give a myopic view of the whole picture of debt announcements and their impact on shareholder wealth. Using a bivariate EGARCH, we estimate time-varying betas and risk-adjusted time-varying returns for a sample of publicly traded firms listed on the London Stock Exchange (LSE). We proceed to examine the beta risk of these firms and show that debt issue announcements generally lead to a rise in the betas. We subsequently examine how the risk-return relationship changes during normal economic conditions and during recessionary periods. Overall, we show that rises in beta risk are markedly more pronounced when aggregate economic sentiment is low (and during our recession sample). Interestingly, alphas (or risk-adjusted returns) increase along with betas only during normal economic conditions. During recessionary periods when beta risk rises more significantly, alphas have a tendency to decline.

Thus, the following themes emerge from our findings. On average, the betas of announcing firms usually rise in varying degrees across time windows following the announcement of a new debt issue. In the five days following the announcement, betas rise by approximately $10 \%$ and by about $14 \%$ in the 6 - to 30 -day window following the announcement. They continue to rise steadily until 99 days following the announcement, suggesting an important upward shift in the systematic risk of announcing firms. When we split the sample on the timing that the event takes place, the betas of firms that issue debt during normal economic periods rise significantly less than those of firms issuing debt during recessionary periods. Interestingly, the time-varying alphas (risk-adjusted returns) of firms making debt announcements during normal economic times rise steadily in the days both preceding and following the announcement date. Conversely, during recessionary periods time-varying alphas experience a precipitous decline and even take on negative values in the three months following the announcement. Finally, in line with the alpha-beta relationship of the two sub-samples, we find that firms whose management opted to make debt announcements during normal economic times display steadily rising time-varying Treynor ratios following the announcement (evidence of a positive riskreturn tradeoff). On the other hand, those firms that made debt announcements during recessionary periods displayed negative time-varying Treynor ratios in the two and three months following the announcement (evidence of a negative risk-return tradeoff).

Such an asymmetry in the time path behavior of beta indicates that economic conditions play a large role in investors' response to debt issue announcements. It also suggests that the undesirable effects of information asymmetry are exacerbated during bad economic times and when investor sentiment is generally low. While during normal economic times investors may be more tolerant to risk and more optimistically receptive to debt announcements, we show that there is an opposite effect during recessionary periods. Declining alpha (while beta rises) suggests that investors focus more on the risk increase and less to the potential future prospects of the firm.

Overall, our findings are in line with behavioral arguments that if investors suffer losses from their risky portfolios, they increase their loss-aversion and/or ambiguity-aversion which lead to revaluation of the asset 
price lower than the risk taking (e.g., see Barberis, 2011; Cabeller and Krishnamurthy, 2008). Hence, during recessionary times, issuing new debt may not be received by investors as a signal for prosperous growth opportunities, but it may instead be perceived negatively and trigger an adverse market reaction.

We contribute to the literature in various ways. First, this paper may serve to reconcile the conflicting evidence regarding the behavior of stock prices following debt announcements. As described in more detail in the second section of this paper, some find that investors react positively to debt announcements while others react negatively. For the past several decades, there is no agreement in event study literature as to what the effects of debt announcements are. Second, our findings shed light onto the role of information asymmetry. While event studies evoke the notion of information asymmetry in order to reconcile conflicting findings and to demonstrate that stock prices can be 'noisy' and difficult to decode following debt announcements, we show that the negative effects of information asymmetry are exacerbated during hard economic times when investor sentiment is low. Outside investors may become more apprehensive toward debt announcements and, in the words of Akerlof (1970), ask themselves whether the underlying firm is selling peaches or lemons. In other words, do inside managers really have positive NPV opportunities that can enhance future earnings, or, will the proceeds from this debt go to suboptimal uses and only serve to raise financial distress costs? Our findings concur that the betas of announcing firms during a recessionary period rise acutely relative to those that make debt announcements during normal economic conditions.

Finally, in an innovation relative to existing event study literature, our paper provides a more complete picture of stock price behavior in the days surrounding debt announcements. We do so by estimating timevarying betas, in order to construct time series of underlying firms' Treynor ratios. This approach is somewhat unique in asset pricing and event study literature, and permits the examination of risk-return dynamics across time by relaxing the restrictive assumption that risk and return are constant across time. ${ }^{2}$

The remainder of our paper is structured as follows. The second section provides a review of literature that serves as a motivational underpinning for our paper. The third section describes the nature of the sampled data, estimation methods and empirically testable specifications we consider. The fourth section details the findings of our article and reports how the risk-return dynamics of announcing firms' common stock can be interpreted. Finally, the fifth section summarizes and concludes this paper.

\section{MOTIVATIONAL LITERATURE \& DEVELOPMENT OF ARGUMENTS}

\subsection{Theories on market efficiency, signalling and information asymmetry}

\footnotetext{
${ }^{2}$ Such a restrictive assumption may yield misspecified parameter estimates since casual observation of financial markets, as well as theoretical work, establish that financial time series exhibit time-varying risk-return dynamics. As mentioned, the majority of event study literature which investigates the impact of debt announcements has exclusively focused on CAR computations in the days following such announcements - a technique that explicitly utilizes 'static' or 'single-period' market-type models (e.g., the CAPM) and which do not allow for time variation in beta risk.
} 
Firms face a complex set of choices when deciding how to finance their operations. Traditionally, there exists a conflict of interest between bondholders and stockholders given that the nature of their stakes in the firm is fundamentally different. Bondholders typically prefer risk-averse strategies since this maximizes the likelihood of them recouping their investment. Stockholders, on the other hand, are more likely to prefer risky projects as this means higher potential rewards. There is a flip side to this as well. If the size of debt grows in relation to equity value, stockholders may end up shouldering the volatility associated with uncertainty over whether the firm can repay this debt or whether there are any contractual stipulations in place prohibiting it from undertaking certain risky projects. This presents some serious considerations that management needs to account for when deciding how to finance their operations.

Assuming market efficiency, it should not matter how a firm decides to finance its operations. Classical asset pricing theory posits that, in an efficient market, the economic information content surrounding corporate events such as debt issue announcements should have no impact on expected returns (Fama, 1991; Friedman, 1953; Yen and Lee, 2008). This is because such risk is diversifiable and the information content of the event is already incorporated into the stock's price. Similarly, the Modigliani and Miller (1958) 'irrelevance proposition' posits that capital structure changes should have no effect on firms' stock prices.

However, the notion that markets are efficient is called to question. Behavioral finance studies demonstrate that there is no current consensus that prices move in accordance with the market efficiency hypothesis, especially in light of evidence suggesting that arbitrageurs are constrained in terms of their abilities to fight mispricing given that their resources may be limited (Shleifer and Vishny, 1997) or because they cannot coordinate and synchronize their efforts in order to become a stronger driving force in the market to correct such mispricing (Abreu and Brunnermeier, 2002; 2003). Among other reasons, Wurgler and Zhuravskaya (2002) argue that stocks are imperfect substitutes of each other and it is thus difficult to eliminate their risk. Such risk may stem from mispricing or event-induced phenomena such as, in the case of our paper, debt issue announcements. Casual observation also does not support the notion of market efficiency, especially if we consider the plethora of hedge funds and active money managers that earn their living scanning the market looking for corporate events in order to set up speculative positions.

The notion that markets are efficient is also very restrictive from the perspective of signalling theory in finance and management. According to Spence (1973), there are intrinsic differences between the degree of information one party possesses over the other party of the transaction. From the perspective of event studies, outside investors realize that they possess less information that insiders and, thus, outside investors are constantly gleaning pieces of news or corporate announcements in order to infer such information. Although the truth will come out eventually, shareholders are, naturally, averse to unduly high levels of risk which can adversely affect their portfolios in the short- and medium-term.

Signalling theory is concerned with decreasing the degree of information asymmetry between two parties involved in a transaction (Spence, 2002) and its use to explain corporate events is gaining momentum in areas such as corporate management, human resource management and entrepreneurship, as well as into the fields of finance, organizational science and accounting (Connelly et al., 2011). It is evident that inside managers 
know more about the firm and its future prospects than do outside investors (Anderson and Prezas, 2003; Chen et al., 2004; Wu and Lee, 2008; Shaw, 2012; Gangopadhyay et al., 2014; Koutmos, 2016; Milian, 2016). In the words of Stiglitz (2002, p.469), information asymmetries result when "different people know different things." Stiglitz (2000) identifies two types of information where asymmetry can arise: i) information regarding quality and ii) information regarding intent. For example, management studies examine how CEOs can signal unobservable qualities about their firm's future potential via their financial statements (Zhang and Wiersema, 2009). In entrepreneurship literature, Certo (2003) examines whether board characteristics provide valuable signals to outside investors. Other studies extend signalling theory to investigate whether the presence of venture capitalists and angel investors (Elitzur and Gavious, 2003) and the involvement of firm founders (Busenitz et al., 2005) provide outsiders with any signals as to the value of the firm.

Despite the growth in signalling theory, it is yet to be applied empirically to a wide range of corporate events, such as the announcement of new debt issues. In the context of debt issue announcements, investors may negatively perceive debt announcements because they question the quality of the firm's investment opportunities (i.e., efficient use of funds to implement positive NPV projects) or, more generally speaking, the debt's overall intent and purpose (Chen and Su, 2010; Carayannopoulos and Nayak, 2013). Our main research question is: How do outside investors interpret new debt issue announcements? Although, as Ross (1973; 1977) posits, this event ought to correlate with a rise in firm value, this may not always be the case if investors interpret this information negatively. We argue herein (and show empirically) that, in line with the opponents of market efficiency, betas following debt issue announcements shift significantly as the company's risk changes.

\subsection{Debt issue announcements}

Recent articles examine the behavior of stock prices following debt issue announcements. In general, the consensus is that debt issue announcements lead to negative AR and with rises in price variance. Spiess and Affleck-Graves (1999) examine US firm data and report significant long-run post-issue underperformance following straight and convertible debt offerings. Lewis et al. (2000; 2002), also examining US firm data, report that firms making convertible debt offerings experience poor long-run stock price performance and there is a rise in the sample firms' risk profile. Most recently, Zeidler et al. (2012) also report findings for the US market by analyzing the impact of convertible bond offerings and seasoned equity offerings, documenting rises in firms' risk profile prior to the date of issuance of both events. Moving away from the US stock market, Amman and Seiz (2006) examine the announcement effects of convertible and exchangeable bond offerings in the Swiss and German markets and also find negative AR following the announcement.

We first contribute to this literature by investigating all types of debt in the UK for which evidence is sparse, after controlling for various issue-specific, firm-specific and market-related factors. By controlling for these factors we are able to disentangle the impact of the actual debt announcement itself and test whether this serves as a 'leverage up' signal, increasing the firm's systematic risk. We argue that a rise in systematic risk (i.e., beta) following a debt increase may reflect stockholders' angst with respect to the firm's ability to shoulder 
more debt. It may also reflect a conflict of interest between existing stockholders and new bondholders. Specifically, to some extent, existing stockholders have an incentive for the firm to undertake relatively riskier projects which bondholders may be risk averse to, and while stockholders can sell their shares in the event these projects become unsuccessful, bondholders may be exposed to prolonged periods of credit risk. Bondholders may also establish contractual stipulations restricting the level of risk the underlying firm can undertake or may demand higher interest payments as compensation for the increased risk. From the perspective of the underlying firm, this leads to a rise in its cost of capital and, to some extent, hinders its ability to earn 'spectacular' upside rewards which stockholders yearn for.

Second, we take a step further compared to the even-study literature that focuses on risk-adjusted returns without considering contemporaneous risk changes, and attempt to answer a natural question that begs for an explanation: What happens to risk-adjusted returns in the presence of rising betas? An answer to this question carries implications for the risk-return tradeoff for investors who choose to hold stock in firms that make debt issues announcements. There is a burgeoning body of literature that attempts to explore the risk-return relation on the market portfolio. The evidence thus far is mixed and there is no consensus as to the sign and magnitude of the risk-return tradeoff. Some report a positive risk-return tradeoff while others find a statistically weak or negative risk-return tradeoff (French et al., 1987; Glosten et al., 1993; Nelson, 1991; Koutmos, 2012). A negative tradeoff appears to be irreconcilable from the viewpoint that we are rational riskaverse individuals and that higher betas ought to be associated with higher expected returns (Koutmos, 2015).

Moreover, inferences drawn from traditional event studies are based on single-period models such as the CAPM or the market model. This procedure is problematic, as it assumes equity risk to be time-invariant across plausible time frames such as day-to-day or week-to-week; an assumption which does not hold. We conjecture that a broader view is needed. We argue that the application of a bivariate EGARCH model is more appropriate, especially considering that volatility changes asymmetrically across time.

Our bivariate EGARCH model allows for time-varying betas and time-varying alphas, which will also allow the time series construction of announcing firms' Treynor ratios. This approach is somewhat unique in asset pricing and event study literature, and permits the examination of risk-return dynamics across time by relaxing the restrictive assumption that risk and return are constant across time periods (an assumption that may yield misspecified parameter estimates).

\subsection{The role of economic recessions}

How an economic recession - and a period of declining sentiment in general - can influence investors' reactions to debt issue announcements is yet to be examined rigorously in extant literature. Specifically, there is an increasing body of literature that deals with the role of investor sentiment on market reactions to the arrival of price-sensitive information. The empirical evidence supports the view that markets tend to penalize 'bad' news more during periods of low sentiment and pessimism than during periods of optimism. For example, Mian and Sankaraguruswamy (2012) investigate the effect of market-wide optimism and pessimism on market reactions to firm-specific announcements in the US market and conclude that sentiment materially moves stock price 
responses in the direction of such sentiment: the impact of 'bad' news is accentuated in the presence of pessimistic sentiment. This evidence is corroborated in a variety of other contexts. Bozos et al. (2011), and references therein, show that the general economic climate can affect the way investors perceive corporate dividends and earnings. Baker and Wurgler (2006; 2007) show that, on aggregate, investor sentiment is a significant determinant of stock returns whereby investor optimism is associated with rising prices and vice versa. More recently, Brown et al. (2012) suggest that during periods of economic optimism, firm management's accounting disclosures are less likely to be evaluated rigorously by outside investors. All of the above support the view that underlying investor sentiment may play an important role in influencing how the market reacts to the disclosure of corporate news.

Information asymmetry is an omnipresent force in financial markets and, in some respects, reflects the degree to which there is divergence of opinion among outside investors regarding the future prospects of a firm. Empirical research, in a variety of contexts, supports the view that the negative connotations associated with information asymmetry can exacerbate during recessions and thereby raise the probability that the market reacts negatively to various firm announcements or news disclosures. Ceteris paribus, an otherwise well-received announcement made during normal economic times may be negatively construed during times of market upheaval. This is, a priori, to be expected because investors are psychologically in a state of flux during bad economic times and more nervous about the prospects of losing their investments.

Empirical studies also support the notion that aversion towards risk can rise when the prospects of losing also rise. In their seminal piece, Tversky and Kahneman (1992) delineate the principle of loss aversion, which highlights the human tendency to strongly prefer avoiding possible losses than to attaining gains of equal magnitude. During recessionary periods, when the probability of losses rises across asset classes, investors become more sensitized to informational asymmetries and the possibility of diminishes in their wealth. Therefore, they are more prone to questioning the quality and intent of a firm's management (i.e., they are more likely to ask whether the firm's management is selling them peaches or lemons, or whether proceeds raised from the new debt issue will be effectively used in implementing positive NPV projects). Thus, an otherwise benign piece of news or announcement may trigger an adverse market reaction during bad economic times.

It remains unexplored whether the overall economic environment can exacerbate information asymmetry and can lead outside investors to negatively value a firm that makes a debt issue announcement. We thus contribute to extant literature and pose the following empirical question: Does the economic environment play a role in explaining the risk-return relationship? We conjecture that periods of optimism (when the economy is in a growth stage) and periods of pessimism (when the economy is in a recessionary stage) affect outside investor sensitivity to information asymmetry differently. We argue that the risk-return tradeoff of debt announcing firms' common stock will differ following debt announcements depending on economic conditions.

Thus, it is natural for betas to rise relatively more when debt issue announcements take place in recessionary periods than when announcements take place during normal market conditions. This is because, consistent with the rationale of Tversky and Kahneman (1992), negative effects of information asymmetry can 
be exacerbated during bad economic times when investor sentiment is low, as outside investors become more apprehensive toward debt announcements. In other words, during recessionary periods, investors will focus more on the intent and quality of debt announcements. They may also question the extent to which such debt will go toward positive NPV projects. In this case, a negative relation between risk and adjusted returns is to be expected. Such a result would also go against the conjectures put forth by Ross $(1973 ; 1977)$ but would shed more light onto how outside investors react during debt announcements made in bad economic times. On the contrary, during normal economic conditions, investors are more likely to believe that inside managers have positive NPV opportunities indeed, and the funds will be used to enhance future earnings. In this case, a positive relation between risk and adjusted returns is to be expected.

\section{SAMPLE DATA \& ANALYTICAL FRAMEWORK}

\subsection{Nature of data sample}

To ascertain the impact of debt issue announcements on the risk-return dynamics of underlying firms we sample the FTSE 100 constituents, which represent the highest capitalization and most liquid stocks in the UK. Such companies are arguably well-established with high visibility, representing the 'blue chips' of the LSE. A sample of debt issue announcements from FTSE 100 companies is manually retrieved by scanning through daily news announcements from the LSE's Regulatory News Service (RNS). We carefully identify the very first official announcement about a company's decision to issue new debt. Announcements made by companies' subsidiaries are excluded from the sample.

All the announcements in the final sample are uncontaminated by other firm-specific and price-sensitive events, such as dividend and earnings announcements, sales announcements, analyst forecasts, mergers and acquisitions, top management changes, and the like. The final sample (shown in table 1) comprises of 194 debt issue announcements during the period spanning January 1, 2003 through December 31, 2010; a seven-year horizon that captures the events of mid-2007, which marked the beginning of the most recent financial recession that economists now refer to as the 'great recession.'

Figure 1 illustrates a time series plot of the FTSE 100 index with dots denoting respective announcements, alongside the UK Economic Sentiment Indicator (UKESI), which is derived from combined business tendency surveys and is published by the Directorate-General for Economic and Financial Affairs (European Commission, 2011). The vertical line through August 9, 2007 marks the beginning of the great recession, or so-called 'credit crunch,' whereby short-term money markets froze leading the European Central Bank and the Federal Reserve to inject emergency liquidity into global financial markets.

The total value of the raised debt during this period exceeds $£ 156$ billion, representing over $10 \%$ of the FTSE 100 market capitalization and over 7.5\% of entire LSE equity market value as of 2012.

[Insert table 1 about here]

[Insert figure 1 about here] 


\subsection{Estimation of abnormal returns (AR)}

Consistent with extant event study literature, it is of interest to compute 'static' AR for our sampled firms in order to gain a preliminary understanding of price behavior before and after firms' announcement of a debt issue. Following Mikkelson and Partch (1986), Slovin et al. (2000) and the majority of event studies (see e.g., Strong, 1992), we employ the familiar single-period market model as a benchmark for measuring the value effect of new debt issue announcements. We regress the logarithmic returns of each security $\left(R_{i t}\right)$ against those of the FTSE 100 market index $\left(R_{m t}\right)$ for an estimation period of 90 days ( $\left.T_{-100}, T_{-11}\right)$ prior to the event day, $T_{0}$, and estimate the return residuals $e_{i t}$ for the period $T_{-5}$ to $T_{+5}$ for all 194 events in our sample:

$$
A R_{i t}=e_{i t}=R_{i t}-\left(\hat{\alpha}_{i}+\hat{\beta}_{i} R m_{t}\right)
$$

Based on (1), we measure average abnormal returns (AAR) and average standardized abnormal returns (ASAR) for the various time windows, as well as the average cumulative abnormal returns (ACAR) and average cumulative standardized returns (ACSAR) for three event windows around $\mathrm{T}_{0}$. We also report the standardized cross sectional (SCS) test, which is a hybrid test of the Patell standardized residual (PSR) test (Patell, 1976). This test adjusts the residuals for forecast error and prevents large variance observations from dominating the test but is more robust when event-induced variance is present. The test for day $t$ is as follows:

$$
Z_{t}=\frac{A S A R_{t}}{\sqrt{\operatorname{Var}\left(A S A R_{t}\right)}}
$$

$A S A R_{t}$ denotes the average standardized abnormal return for the day $t$, formulated as in (3) below:

$$
\begin{gathered}
A S A R_{t}=\frac{1}{194} \sum_{i=1}^{194} S A R_{i t}, \\
S A R_{i t}=\frac{A R_{i t}}{\hat{\sigma}_{i t}}, \\
\hat{\sigma}_{i t}=\hat{\sigma}_{i}+\frac{1}{90}+\frac{\left(R_{m t}-\bar{R}_{m t}\right)^{2}}{\sum_{t^{*}=-100}^{-11}\left(R_{m t *}-\bar{R}_{m t *}\right)^{2}} .
\end{gathered}
$$

where $S A R_{i t}$ is the standardized abnormal return for security $i$ at day $t, \bar{R}_{m t}$ is the mean market return during the whole period $\left(T_{-110}, T_{+10}\right)$, and $\bar{R}_{m t^{*}}$ denotes the mean market return during the estimation period ( $T_{-110}, T$. 11)The appropriate test statistic for the abnormal cumulative standardized returns for a period $L$ within the event period is:

$$
Z_{L}=\frac{A C S A R_{t}}{\sqrt{\operatorname{Var}\left(A C S A R_{t}\right)}}
$$

whereby $A C S A R_{t}=\frac{1}{194} \sum_{i=1}^{194} C S A R_{i t}, C S A R_{i t}=\frac{1}{\sqrt{L}} \sum_{t=1}^{L} S A R_{i t}$, and $L$ is equivalent to the number of days within the period. 
Finally, we employ a binomial sign test, which (as a test of location) is not influenced by positive or negative outliers and can thus act as a reliable non-parametric robustness procedure (McConnell and Muscarella, 1985). The z-statistic for this test is:

$$
Z=(p-n r) / \sqrt{n(1-r) r},
$$

whereby $p$ is the number of positive returns during the event period, $n$ is total number of returns during the same period and $r$ is the percentage of positive returns during the estimation period (51.54\%).

\subsection{Economic recession and control variables}

To test the role of the economic environment on the AR surrounding debt issue announcements, we employ the dummy variable RECESS, which equals 0 for all announcements prior to August 9, $2007(\mathrm{~N}=109)$ and 1 for the following observations ( $\mathrm{N}=85$ ). To validate the results under a more robust setting, we also employ the UK Economic Sentiment Indicator (UKESI), to examine the role of general economic sentiment on the market's reaction to debt issue announcements.

To control for anticipated effects by known AR determinants, we employ three vectors of issue-specific, firm-specific and market-related control variables. For issue-specific variables, we use LOGDEBT, the natural logarithm of the debt value to control for the size effect of equity issues on stock price movements; EURO is a dummy variable that equals 1 if the debt was issued in Euros and is 0 otherwise; PRIVATELOAN is a dummy variable that equals 1 if debt was raised via some private arrangement or credit facilities and is 0 otherwise; CONVERT.BOND is a dummy variable that equals 1 if the bond issue contains a convertibility option and is 0 otherwise. Note that if a bond issue does not have a convertibility option, it is considered a straight bond or a plain vanilla bond. USE OF FUNDS is another issue-specific dummy variable that takes the value of 1 if the debt was used for growth and is 0 for capital restructuring; 1-OFF ISSUE is a dummy variable which aims to control for the presumably lower market reactions to debt issued under a predetermined and preannounced program (where the dummy variable takes a value of 0 ) in contrast to those issued as 'one-off' events (where the dummy variable takes a value of 1 ).

Let us now turn our attention to the firm-specific control variables. \%OFTA represents, as an additional size-effect control, the fraction of the debt value to total assets; OPER.PROFIT aims to control for operating firm profitability; $M T B V$ is the equity market-to-book value of the underlying firm; LTDTOTA is long-term debt to total assets; LOGAGE measures, in log terms, the years that the company has been in existence; finally, to control for anticipated reactions to high price run-ups (Masulis and Korwar, 1986) we use RUNUP for the 90 days (T. 100, $\mathrm{T}_{-11}$ ) cumulative share price returns. This RUNUP variable controls for the possibility that prices appreciate

prior to the announcement date, $\mathrm{T}_{0}$, whereby such appreciations stem from factors irrelevant to the announcement itself. It is by now well-known among practitioners and academics that firm insiders may delay corporate decisions or announcements which they know will likely be ill-received by the market. Instead, they may 'time' such events during periods when their company's stock price has steadily risen (Myers and Majluf, 1984). 
In addition to the issue-specific and firm-specific variables, we also employ two market-related variables. 3ODMKTVOL is the realized 30-day volatility of the FTSE 100 index to represent aggregate market volatility; TSPREADS\% is the spread between the 1-month and 30-year gilts and represents the yield curve in the United Kingdom. Integrating all the aforementioned recession and control variables, our extended cross-sectional model is as follows:

$$
\begin{aligned}
& \operatorname{CAR}\left(T_{-1}, T_{0}\right)=\alpha_{1}+\beta_{1} \text { LOGDEBT }+\beta_{2} \text { EURO }+\beta_{3} \text { PRIVATELOAN }+\beta_{4} \text { CONVERT.BOND }+ \\
& \beta_{5} \text { USE OF FUNDS }+\beta_{6} 1 \text {-OFFISSUE }+\beta_{7} \% \text { OFTA }+\beta_{8} \text { OPER.PROFIT }+\beta_{9} \text { MTBV }+ \\
& \beta_{10 L T D T O T A}+\beta_{11} \text { LOGAGE }+\beta_{12} \text { RUNUP }+\beta_{13} 30 D M K T V O L+\beta_{14} \text { TSPREADS } \%+ \\
& \beta_{15} \text { RECESS }+\beta_{16} \operatorname{UKESI}(\%)+\varepsilon t
\end{aligned}
$$

It is important to note that variations in UKESI seem to correspond with general sentiment in the aftermath of the Lehman Brothers crash. Specifically, and as is graphically shown in figure 1, sentiment begins to decline steadily after August 9, 2007 - the time when Lehman shut down BNC Mortgage, its subprime lending unit. Events transpiring thereafter went from bad to worse as the investment banking community at large fretted over the possibility of a prolonged global recession that would stifle economic growth and entrepreneurship. Finally, and to complete the discussion of this subsection, model (6) is estimated using ordinary least squares with heteroskedasticity-consistent standard errors (White, 1980).

\subsection{Estimation of time-varying betas, alphas and Treynor ratios}

It is well-established by now in asset pricing that volatility is time-varying in nature and responds asymmetrically to positive and negative shocks in market returns. GARCH-type models have proved to be very successful in capturing many 'stylized facts' observed in the time-series properties of stock returns such as volatility persistence and clustering and have thus become the de facto standard for estimating volatility.

In the last few years we have thus seen a surge in the development of various GARCH-type models given their success in modelling the time series volatility dynamics of asset returns. As Cuthbertson and Nitzshe (2004, p.664) jokingly maintain, there exist more variations of the GARCH process 'than there are varieties of breakfast cereals...'

Given that market downswings ('bad' news) leads to more volatility than upswings ('good' news) of equal magnitude, the traditional GARCH model has been extended to accommodate such asymmetry in volatility caused by stock price behavior.

Such GARCH variants have been examined and assessed extensively; among many others, Pagan and Schwert (1990) evaluate several volatility models and conclude that the exponential GARCH (EGARCH) of Nelson (1991) provides the best overall 'fit' for return volatility. Likewise, Engle and Ng (1993) conclude the EGARCH does very well in capturing asymmetries in stock return volatility.

Given the aforementioned evidence, we model time-varying betas using a bivariate EGARCH that can be described as follows;

$$
\begin{aligned}
& R_{i, t}=\omega_{i, t}+\beta_{i, t} R_{m, t}+\varepsilon_{i, t} \\
& R_{m, t}=\omega_{m, t}+\varepsilon_{m, t}
\end{aligned}
$$


whereby $R_{i}$ denotes the returns of the individual stock and $R_{m}$ denotes the returns of the aggregate market portfolio. The time-varying beta estimate is represented by $\beta_{i}$ for the individual stock and shifts across time in accordance with news regarding the underlying firm $i$ and market sentiment. Finally, the constants are denoted as $\omega_{i}$ and $\omega_{m}$ and the innovations, or error terms, are $\varepsilon_{i}$ and $\varepsilon_{m}$ for the individual stock and the market, respectively.

Elements of the variance and covariance matrix for the two error terms can be described using a bivariate EGARCH;

$$
\begin{aligned}
& \sigma^{2}\left[\varepsilon_{i, t}\right]=\exp \left(\alpha_{i, 0}+a_{i, 1}\left(\left|z_{i, t-1}\right|-E\left|z_{i, t-1}\right|+\gamma_{i} z_{i, t-1}\right)+\theta_{i} \ln \left(\sigma^{2}\left[\varepsilon_{i, t-1}\right]\right)\right) \\
& \sigma^{2}\left[\varepsilon_{m, t}\right]=\exp \left(\alpha_{m, 0}+a_{m, 1}\left(\left|z_{m, t-1}\right|-E\left|z_{m, t-1}\right|+\gamma_{m} z_{m, t-1}\right)+\theta_{m} \ln \left(\sigma^{2}\left[\varepsilon_{m, t-1}\right]\right)\right) \\
& \sigma_{i, m, t}=\rho_{i, m}\left(\sigma^{2}\left[\varepsilon_{i, t}\right] \sigma^{2}\left[\varepsilon_{m, t}\right]\right)^{1 / 2}
\end{aligned}
$$

where the normalized innovations for each individual stock, $z_{i}$, and the market portfolio, $z_{m}$, can be expressed as follows for each sampled day $t: z_{i, t}=\varepsilon_{i, t} / \sigma\left[\varepsilon_{i, t}\right]$ and $z_{m, t}=\varepsilon_{m, t} / \sigma\left[\varepsilon_{m, t}\right]$. The conditional covariance as well as the conditional correlation coefficient are denoted by $\sigma_{i, m, t}$ and $\rho_{i, m}$, respectively. The remainder of the bivariate EGARCH parameters are fixed and to be estimated; $\alpha_{i, 0}, \alpha_{m, 0}, a_{i, 1}, a_{m, 1}, \gamma_{i}, \gamma_{m}, \theta_{i}$ and $\theta_{m}$, respectively. Volatility persistence is captured by the parameters $\theta_{i}$ and $\theta_{m}$, respectively.

The bivariate EGARCH specification in (8) is advantageous in at least two respects. First, the conditional variance, $\sigma^{2}$, responds asymmetrically to 'good' and 'bad' news. This asymmetry is captured by $\gamma_{i}$ and $\gamma_{m}$ for the conditional variance of the individual stock and the market portfolio, respectively. Specifically, a negative sign for these coefficients implies that 'bad' news (negative return innovations) leads to more volatility than 'good' news (positive return innovations) of equal magnitude. Second, unlike traditional GARCHtype models, the log-linear nature of the EGARCH specification precludes the possibility of estimating a negative conditional variance for any given sampled time period and thus does not require that we impose nonnegativity constraints.

Time-varying betas, $\beta_{i}$, can be extracted from (7) and (8) for each individual sampled stock;

$$
\beta_{i, t}=\left(\sigma_{i, m, t}\right) /\left(\sigma^{2}\left[\varepsilon_{m, t}\right]\right)
$$

and, since the conditional covariance, $\sigma_{i, m, t}$, as well as conditional variance of returns for the market portfolio, $\sigma^{2}\left[\varepsilon_{m, t}\right]$, are time-varying, beta is also time-varying and evolves in accordance with corporate events, shifts in investment opportunities, market sentiment and, finally, perceived prospects associated with the underlying stock $i$.

Estimating time-varying betas in (9) is advantageous in that it permits the survey of a stock's beta risk over finer time granularities relative to betas deduced from 'static' asset pricing models such as the singleperiod CAPM. Thus, by examining a stock's beta risk day-to-day one can, for example, decipher the impact of certain events confined within a particular day while the impact of such an event would otherwise be distorted when using the single-period CAPM to produce point estimates of beta. This is because point estimates of betas, even in a rolling regression framework, depend on observations before and after an event of interest - 
observations which may otherwise be irrelevant and not representative of the nature of the event we wish to capture.

When estimating parameters for the bivariate EGARCH in (8), we assume the error term is drawn from a normal density distribution (Hentschel, 1995) and by maximizing the likelihood function over the sampling periods which can be expressed as follows;

$$
L(\Theta)=-(T / 2) \log (2 \pi)-(1 / 2) \sum_{t=1}^{T}\left(\log \left|H_{t}\right|+E_{t} H^{-1} E^{\prime}\right)
$$

where $T$ denotes the number of observations, $\Theta$ is the vector parameter to be estimated, $E_{t}=\left[\varepsilon_{i, t}, \varepsilon_{m, t}\right]$ is the vector of innovations at sample time $t$ and $H_{t}=\operatorname{Cov}_{t-1}\left(E_{t}\right)$. Given that nonlinearities exist in the log likelihood function, we employ numerical maximization techniques to obtain sample parameter estimates using the algorithm based on Berndt et al. (1974).

Although it serves many useful purposes to try and deduce how announcing firms' time-varying betas change before and after announcements, a more complete picture can be achieved by specifically looking at time-varying risk-adjusted returns. Whereas solely examining time-varying betas using (9) can lead to inferences regarding how announcing firms' systematic risks shift, it is silent on how returns behave or whether shareholders are compensated for commensurate shifts in such risk.

Thus, in addition to time-varying betas, we also extract 'time-varying alphas,' $\alpha_{i}$, for each firm which signify the 'portion' of return over and above what is predicted by the time-varying beta in (9) when each firm's realized returns are regressed against these time-varying betas. Keeping the same notation that is used in describing equations (7) and (9), we can express $\alpha_{i}$ as follows;

$$
a_{i, t}=R_{i, t}-\beta_{i} R_{m, t}
$$

In addition to time-varying alphas, we construct 'time-varying Treynor ratios' as another means to gauge firms' excess returns per unit of market risk;

$$
\text { Treynor } \text { ratio }_{i, t}=\frac{R_{i, t}-R_{f, t}}{\beta_{i, t}}
$$

Given that our measures for time-varying alphas and Treynor ratios, respectively, express riskadjusted returns, it is expected that both will yield qualitatively identical results.

\section{EMPIRICAL FINDINGS}

\subsection{The determinants of abnormal returns}

Table 2 provides the mean AR and preliminary univariate tests of means for our sample, addressing our question on how the market reacts to a debt issue announcement. Panel A documents the AAR and ASAR for the various time windows, while Panel B reports the average ACAR and ACSAR for three event windows around $\mathrm{T}_{0}$, namely $\left(\mathrm{T}_{-1}, \mathrm{~T}_{+1}\right),\left(\mathrm{T}_{-1}, \mathrm{~T}_{0}\right)$ and $\left(\mathrm{T}_{0}, \mathrm{~T}_{+1}\right)$. These time windows signify average cumulative abnormal returns one trading day before and after the debt issue announcement day, $\mathrm{T}_{0}$. This tight window represents a time when traders with an eye for news may move prices in one direction or another and (re)position themselves 
in order to reap potentially 'quick' profits. Thus, these announcements signal an important shift in the debt structure of firms and have the capacity to change the risk and return characteristics of announcing firms' common stock. It is also the time when we would naturally expect to see a general (market) reaction given that debt issue announcements carry implications for how the underlying company will restructure its debt.

All parametric and non-parametric tests in table 2 support the notion that debt issue announcements are linked with negative market reactions. Such negative AR are somewhat evident during the pre-announcement period ( $\left.\mathrm{T}_{-3}, \mathrm{~T}_{0}\right)$ and are especially pronounced on the day of the announcement, $\mathrm{T}_{0}$; the AAR computed from all sampled firms on this day is $-0.26 \%$. Likewise, the ACAR on the announcement day $\mathrm{T}_{0}$ is $-0.35 \%$. These negative AAR for the UK market echo findings of studies examining the implications of debt announcements in other countries (e.g., Amman and Seiz (2006) for Switzerland and Germany).

[Insert table 2 about here]

As one of our principal objectives is to examine the role of the recession on the market's reactions to debt issue announcements, table 3 reports the market reaction results from univariate tests of means and mean differences in ACARs after splitting the sample by the dummy variable RECESS, with the cut-off point being August 9, 2007 (in Panel A). In addition, and as a robustness procedure, we entertain the possibility that broader market sentiment plays a role in terms of the reaction to debt issue announcements. Thus, in Panel B, we split the sample on the basis of the level of the UK Economic Sentiment Indicator (UKESI) during the period surrounding the announcement day whereby UKESI>100 denotes above average sentiment levels while $U K E S K<100$ indicates below average sentiment levels.

The recessionary sample documents significantly lower AR compared to those of non-recessionary. All two-day mean differences in AR are negative, ranging from $-0.08 \%$ to $-0.57 \%$ for the first set of comparisons in Panel A and from $-0.47 \%$ to $-0.76 \%$ for the second set in Panel B. Even more interesting is the fact that ACARs in the non-recession samples (RECESS $=0$ and/or UKESI $>100)$ are very close to zero and statistically nonsignificant, while within the recessionary samples $($ RECESS $=1$ and/or UKESI $<100)$, all two day ACARs are negative and statistically significant at least at the $5 \%$ level (except during $\left(\mathrm{T}_{0}, \mathrm{~T}_{+1}\right)$ based on RECESS $=1$ (Panel A) where there is no statistical significance). This suggests that the surrounding economic sentiment may act as a predictor of average AR surrounding debt issue announcements. In positive sentiment periods, debt issue announcements appear to go unnoticed while in periods of contraction and decline, debt issue announcements are accompanied by negative and statistically significant excess returns.

These preliminary findings shed light onto how recessionary periods exacerbate outside investors' sensitivity to information asymmetry. Specifically, during periods of low sentiment, investors become possibly more loss averse and question the quality and intents of firms' management when announcing new debt issues. This may lead to some investors exiting their positions and instead opting to wait to see the true intentions of management and their abilities to implement positive NPV projects. This applies downward pressure on prices and thus we see the negative ACARs which we report. Management's timing of debt issue announcements is thus important because this will directly impact their stock's price; in times of economic upheaval, there may 
be a sharper than usual downward reaction in their company's stock price if they choose to announce the issuance of debt securities.

$$
\text { [Insert table } 3 \text { about here] }
$$

To examine whether the qualitative nature of the above conclusions hold in the presence of firm-specific, issue-specific and market-wide controls, we employ the cross-sectional model described in (6). In Panel A of table 4 we present the correlation matrix of all the variables employed in the analysis and in panel B we display key summary statistics.

[Insert table 4 about here]

In table 5, we report the results from six consecutive OLS regression models. The first four models (models 1 through 4) report each 'class' of control variables namely, issue-specific (model 1), firm-specific (model 2) and market-related (models 3 and 4) variables, respectively. The latter set also investigate our research question on whether investor sentiment affect the market reactions around debt issue announcements. Models 5 and 6 are referred to as 'full' models because they report our economic conditions variables as well as all control variables. These models test the explanatory power of the issue-specific, firm-specific and marketrelated factors when they are included together and they collectively exert an influence on CARs.

When we we test the effect of all issue-level variables in model 1, we find that CARs react negatively when debt is issued in Euros, but positively when they are a 'one-off' issue. In other words, the market reacts negatively if the debt is not in British pounds but in Euros, and it reacts positively to the debt issue if the company does not frequently issue debt (and therefore does not intend to issue debt again in the near future). In model 2, none of the firm-level controls is flagged as significant and the model has essentially no explanatory power. In both models 3 and 4, which test market-level variables, the coefficient for the share price run-up is negative and significant suggesting that share prices react more negatively for high pre-announcement runups, as is expected. This shows that investors are able to recognize when the debt issue is timed around a company's upward price trend and react negatively.

The two main explanatory variables, RECESS (from model 5) and UKESI (from model 6), which proxy for economic sentiment are also flagged as significant and bear the expected signs. The coefficient of the dummy variable RECESS is negative $(-0.007, \mathrm{p}$-value $<0.05)$ and suggests that in the recession period share price reactions to debt issue announcements in the LSE exhibit, ceteris paribus, negative abnormal returns. Consistent with the above, the coefficient for UKESI is positive and significant, meaning that across the entire sample, the higher (lower) the economic sentiment the higher (lower) the two-day abnormal returns will be around the event announcement.

As indicated by the full model estimations (models 5 and 6) the above results are robust to the inclusion of all control variables. The value of the adjusted $R^{2}$ and the $\mathrm{F}$ values across the models are somewhat consistent with empirical literature that seeks to explain cumulative abnormal returns following some event of interest (Madura and Akhigbe, 1995).

[Insert table 5 about here] 


\section{2. 'Single-period' betas and alphas}

Contemporary asset pricing supports the notion that risks and returns vary dynamically across time and this serves as a motivation for many of the advances in intertemporal asset pricing. For a multitude of reasons however, academics and practitioners refer to betas and alphas extracted from the single-period CAPM or market model in order to draw inferences. To maintain tradition, and before proceeding to examine the timevarying dynamics of issuing firms' risk and return characteristics following debt announcements, let us consider what can be deduced by scrutinizing our sampled firms' 'static' betas and alphas that are implied by a single-period CAPM.

The findings from the CARs in section 3.2 and table 2 suggest debt issue announcements are generally associated with negative short-term market reactions. As table 3 reports, such negative short-term reactions appear more pronounced during our sampled recession period. Given the longer term implications associated with debt issue announcements, it is of interest to see, firstly, whether we can detect shifts in such 'singleperiod' betas and alphas across relatively longer time horizons.

Consistent with the method used by Grullon et al. (2002) and Charitou et al. (2011) for measuring shifts in CAPM-derived betas and alphas across time windows, we estimate the following regression:

$$
r_{i t}-r_{f t}=a_{i}+a \Delta_{i} D_{t}+b_{i}\left(r_{m t}-r_{f t}\right)+b \Delta_{i} D\left(r_{m t}-r_{f t}\right)_{t}+\varepsilon_{t}
$$

where $D$ is a dummy variable that takes a value of 1 for $t \geq T_{0}$ and 0 otherwise, whereby $T_{0}$ denotes the day of the debt issue announcement; $r_{i t}$ is the daily return of stock $i ; r_{f t}$ is the daily return of the 1-month UK treasury bill; $r_{m t}$ is the daily return on the FTSE 100 market index.

For our full sample and then our non-recessionary and recessionary samples, we estimate (13) for the 200 days surrounding the announcement day, $T_{0}$. The coefficients of principal interest are $a$ and $b$. In this case, $a$ (alpha) denotes firm $i$ s risk-adjusted (or abnormal) returns while $b$ (beta) signifies firm $i$ 's systematic risk. However, (13) makes a distinction between estimated alphas and betas preceding and following the announcement date, $T_{0}$. Specifically, while $a_{i}$ represents alpha prior to $T_{0}, a \Delta_{i}$ is the change in the underlying firm's alpha following $T_{0}$. Similarly, while $b_{i}$ represents beta prior to $T_{0}, b \Delta_{i}$ is the change in the underlying firm's beta following $T_{0}$.

Cross-sectional mean and median values for alphas and betas (and their changes), in (13) are all reported in table 6 for the full, non-recessionary and recessionary sample periods. The final column reports the differences between the non-recessionary and recessionary sub-sample coefficients. The significance levels of the means are based on two-tailed T-tests while those of the medians are based on two-tailed Wilcoxon rank tests.

The results of the full sample suggest that debt issue announcements are in general accompanied by negative risk-adjusted returns. The coefficient $a \Delta_{i}$ is approximately -0.0002 or $-0.02 \%$ while before $\mathrm{T}_{0}$, the coefficient denoting risk-adjusted returns $\left(a_{i}\right)$ was 0.0003 or $0.03 \%$. The $a \Delta_{i}$ and $a$ for the non-recessionary and recessionary sub-samples are similar to the full sample. Nevertheless, the differences in means, albeit 
statistically significant at the $10 \%$ level for $a \Delta_{i}$, suggest that risk-adjusted returns are lower when debt issue announcements take place during recessionary period.

\section{[Insert table 6 about here]}

Regarding the underlying firms' beta risks, they tend to generally rise following the announcement of a debt issue, irrespective of the increase in risk adjusted return. For the full sample, the coefficient $b \Delta_{i}$ is 0.007 (mean) and 0.005 (median). While for the non-recessionary sub-sample period the coefficient $b \Delta_{i}$ drops slightly, for the recessionary sample it rises by 0.018 (mean) and 0.026 (median). The differences in the mean and median between the two sub-samples, are statistically significant at the $5 \%$ level. This provides some evidence that betas tend to rise in general following debt issue announcements (as can be seen in the full sample). However, such rises are more pronounced following announcements that take place during recessionary periods.

Once we combine the findings on alphas with those on betas, we deduce the following: There appears to be an overall positive risk-return tradeoff (considering the alphas $\alpha_{i}$ and betas $b_{i}$ ) in our full sample, which is consistent with the theoretical predictions. However, this relationship reverses and becomes negative following debt announcements (considering the change coefficients, where $a \Delta_{i}$ is positive but $b \Delta_{i}$ is negative, albeit not statistically significant). In other words, betas rise in the overall sample even when we observe a fall in risk-adjusted returns. Interestingly, when observing the risk-return relationship of the two sub-samples we can deduce the following: there appears to be a positive risk-return tradeoff following announcements in our full sample. In other words, although betas rise in the overall sample we also observe a rise in risk-adjusted returns. However, in the recessionary sample, betas tend to rise relatively more yet risk-adjusted returns drop. This is evidence of perhaps a negative risk-return tradeoff.

This evidence serves as a caution for inside corporate managers seeking to make debt issue announcements. It appears that the 'signalling' of debt may result in either a positive or negative risk-return tradeoff depending on the general economic climate. If the economic climate is generally negative, shareholders may experience a rise in beta risk and a simultaneous decline in risk-adjusted returns. Importantly, the findings from (13) also indicate that betas and returns are time-varying in nature. Although asset pricing literature generally supports the notion that risks and returns are time-dependent, event study literature in corporate finance has traditionally relied on single-period CAPM-type specifications to try and draw inferences. We therefore proceed in the next sub-section, by addressing the above empirical gap.

\subsection{Time-varying betas, alphas and Treynor ratios}

We expound on the notion that risks and returns are in fact time-varying. We therefore estimate our sampled firms' time-varying betas, alphas and, ultimately, Treynor ratios in an effort to ascertain the impact of a debt issue in the days surrounding the announcement date, $\mathrm{T}_{0}$ for our full, non-recessionary and recessionary sample periods. We use time-varying betas as estimated in (9) using the bivariate EGARCH expressed in (7) and (8), which provide the opportunity to examine firms' risk on a day-to-day basis in the time period surrounding the announcement date. In order to make conclusions regarding the impact of debt issue 
announcements on stocks' beta risk, we estimate (9) for each stock in our sample from $\mathrm{T}_{-99}$ until $\mathrm{T}_{+99}$. We then average all the individual betas from each stock $i$ in order to produce a plot of these 'aggregated' betas to get an understanding of what happens, on average, when a firm announces a debt issue.

This plot can be seen in Figure 2. Panel A contains the aggregate betas for the entire sample while panels $\mathrm{B}$ and $\mathrm{C}$ contain aggregate betas for the non-recessionary and recessionary sample periods, respectively. Visual inspection of the figures suggests that after the announcement date, $\mathrm{T}_{0}$, beta risk has a tendency to rise, on average, and remain at elevated levels even a month afterwards for the full sample period. Of course, and as is a recurring theme throughout this paper, betas seem to rise more markedly during the recessionary sample period (panel C).

\section{[Insert figure 2 about here]}

Summary statistics in Panel A of Table 7 (for the entire sample consisting of 194 individual firms) also provides a story that corroborates what we see visually from Panel A of Figure 2. Specifically, there is a rise in time-varying betas immediately following the announcement. For the full sample of firms, beta rises by an average of approximately $10 \%$ in the immediate days following the announcement $\left(\mathrm{T}_{0}, \mathrm{~T}_{+5}\right)$. In the $\mathrm{T}_{+6}, \mathrm{~T}_{+30}$ window following the announcement, beta rises by an average of approximately $14 \%$ and, in the $\mathrm{T}_{+30}, \mathrm{~T}_{+99}$ day window, it is higher by an average of approximately $23 \%$ when compared to its level immediately before the announcement (T-50,T-1).

Regarding the non-recessionary (recessionary) sub-samples, beta rises by approximately $10 \%$ (11\%), by $10 \%(19 \%)$ and by $17 \%$ (37\%) during the three time windows post-announcement, respectively. More specifically, if we focus on announcements made during the non-recessionary period, betas rise on average by approximately $10 \%$ during the days following the announcement from 0.9291 during the ( $\left.\mathrm{T}_{-50}, \mathrm{~T}_{-1}\right)$ window to 1.0269 during the $\left(\mathrm{T}_{0}, \mathrm{~T}_{+5}\right)$ window. Afterwards, beta remains relatively flat and only rises to an average of approximately 1.0858 during the $\left(\mathrm{T}_{+31}, \mathrm{~T}_{+99}\right)$ window. For the recessionary period, rises in beta are more pronounced. Within the 5 days immediately following the announcement, $\left(T_{0}, T_{+5}\right)$, firms' betas rise on average by approximately $11 \%$, from 1.129 to 1.256 . In the $\left(T_{+6}, T_{+30}\right)$ window they rise to 1.3421 , a $19 \%$ increase from the 1.1294 during $\left(\mathrm{T}_{-50}, \mathrm{~T}_{-1}\right)$ window. This is in sharp contrast to what was calculated in the $\left(\mathrm{T}_{+6}, \mathrm{~T}_{+30}\right)$ window for the full and non-recessionary samples, respectively. The rise in beta only becomes more intense during the $\left(\mathrm{T}_{+31}, \mathrm{~T}_{+99}\right)$ window when we see it rise by an average of approximately $37 \%$.

This asymmetric behavior in beta risk is consistent with the notion that an attempt to 'signal' markets via new debt issue announcements during bad economic times may result in exacerbated levels of systematic risk for their firm. It appears that as risk aversion levels increase during recessionary periods, the betas rise asymmetrically at extremely high levels.

\section{[Insert table 7 about here]}

This asymmetric behavior in beta is confirmed using an OLS regression approach with time dummies for each of the aforementioned time windows. Coefficients for these dummies as well as their statistical significance are reported in Table 8. In Panel A, we present the time dummies for firms' time-varying betas, while in panel B we show the time dummies for their time-varying alphas, as expressed in (11). These alphas 
(which represent risk-adjusted returns) are unique in the sense that they are estimated from time-varying betas. Figure 3 is a time series plot of the cumulative time-varying alphas across the full and the two period sub-samples.

$$
\begin{aligned}
& \text { [Insert table } 8 \text { about here] } \\
& \text { [Insert figure } 3 \text { about here] }
\end{aligned}
$$

Finally, and complementary to the time-varying alphas, we construct time-varying Treynor ratios using (12). As betas are time-varying, this Treynor ratio evolves daily as well. Similar to the alpha, Treynor ratios measure excess returns per unit of market risk. Put another way, it is a risk-adjusted measure of excess returns and, similarly to alpha, a portfolio management metric that measures excess reward when accounting for additional risk (variability). Table 9 contains time dummy regression estimates for the Treynor ratios for each respective time window for the full sample, non-recessionary and recessionary sample periods, respectively. Finally, figure 4 is a time series plot of time-varying Treynor ratios for each of the sampling periods.

[Insert table 9 about here]

[Insert figure 4 about here]

When examining the time-varying risk-return dynamics of the full sample, the following conclusions emerge. Firstly, there appears to be a discernible rise in beta risk following the announcement of debt. The announcement date, $\mathrm{T}_{0}$, serves as a prelude to the capital structure changes that will ensue and thus serve as a 'signal' for shareholders that the underlying firm will 'leverage up' relative to the value of its equity. Although this conclusion can be drawn by visual inspection of panel A of Figure 2 and by observing the means of betas across various time windows following $\mathrm{T}_{0}$ in Table 7, statistical analysis in Table 8 appears to corroborate this view. In Panel A of Table 8, we document that dummy variables for time-varying betas for both time windows $\left(\mathrm{T}_{6}, \mathrm{~T}_{30}\right)$ and $\left(\mathrm{T}_{31}, \mathrm{~T}_{99}\right)$ are positive and statistically significant at the $5 \%$ level at least. This supports the view that in about one trading week following $\mathrm{T}_{0}$, beta risk for the announcing firm begins to rise steadily.

If we now turn our attention to how risk-adjusted returns behave following $\mathrm{T}_{0}$, we will be in a better position to answer whether shareholders are rewarded for the rises in beta risk. If we visually inspect Figures 3 and 4 which show time series plots of time-varying alphas and time-varying Treynor ratios, we can ascertain that there is a general trend upwards in risk-adjusted returns following $\mathrm{T}_{0}$ for the full sample. In line with this, statistical analysis reported in Panel B of Table 8 corroborates this view. There is statistical significance at the $1 \%$ level for time-varying alpha dummies in all windows following $\mathrm{T}_{0}$. In fact, in the time window $\left(\mathrm{T}_{-50}, \mathrm{~T}_{-1}\right)$ there is evidence that time-varying alphas begin to rise even prior to $\mathrm{T}_{0}$. There is no readily available explanation to this other than it may constitute an expectation of an announcement by insiders and whereby such information may begin to leak to the public. Table 9 shows qualitatively identical conclusions. These findings thus so far, for the full sample, offer an affirmative answer to the abovementioned question of whether beta risk is rewarded.

Naturally, the next step in our analysis is to examine whether the recent great recession of 2007-2008 played a role in terms of how beta risk responded to debt issue announcements. Consistent with classical corporate finance theory we expect investors' discount rate to be linked with their opportunity cost of capital 
and their degree of loss aversion. It is therefore reasonable to expect that in times of economic turbulence (when information asymmetries and divergences of opinion regarding what the future holds are most pronounced) investors' opportunity costs may naturally rise along with their required rate of return. During such times of overall low economic sentiment, the conflicts of interest between bondholders and stockholders may reach exacerbated levels and bondholders will be particularly sensitive to risky projects which stockholders are keen to undertake in hopes of achieving high returns.

Indeed, after dividing our sample between non-recession and recession periods in Figure 2 we observe a certain level of asymmetry across beta reactions. Specifically, debt-announcing firms in the recessionary period experience a discernibly sharper rise in their beta risk to those in the non-recessionary sample. In line with this are the univariate findings in Table 7 and the time dummy regression results in Table 8, which also corroborate this asymmetric behavior in betas. Panel A of Table 8 shows that in the time windows $\left(\mathrm{T}_{6}, \mathrm{~T}_{30}\right)$ and $\left(\mathrm{T}_{31}, \mathrm{~T}_{99}\right)$, respectively, betas for the recessionary sub-sample are higher than those on the non-recessionary sub-sample. For the sake of comparison, the last column of Panel A shows the differences between the non-recessionary and recessionary sub-samples. The differences for the time windows $\left(T_{6}, T_{30}\right)$ and $\left(T_{31}, T_{99}\right)$, respectively, are positive and statistically significant at the $1 \%$ level. Thus far, such an observed asymmetry in the behavior of beta is consistent with the notion that the economic climate leads to relatively sharper rises in beta risk.

Having ascertained the asymmetric behavior of beta risk following $\mathrm{T}_{0}$ in non-recessionary versus the recessionary sample period, let us consider, as was posed in the question earlier, whether such risk is in fact rewarded. For the non-recessionary sample, there appears to be in Figure 3 (Panel B) a reward for the modest rises in beta risk. This is confirmed also statistically in Panel B of Table 8 (time-varying alphas) and Table 9 (time-varying Treynor ratios). Specifically, we detect positive and statistically significant values for timevarying alpha dummy variables that capture all time windows following $\mathrm{T}_{0}$. In Table 9 we again ascertain qualitatively similar conclusions.

However, for the recessionary sample in Figure 3 (Panel C), although there are positive time-varying alphas for the time windows $\left(T_{0}, T_{5}\right)$ and $\left(T_{6}, T_{30}\right)$, they are noticeably lower than the respective windows for the non-recessionary sample. This is an indication that risk-adjusted returns are lower despite the higher beta risk associated with the recession. In addition, for the time window $\left(\mathrm{T}_{31}, \mathrm{~T}_{99}\right)$, mean alphas turn negative and are statistically significant at the $5 \%$ level. This suggests that after about two trading months, a negative riskreturn trade-off manifests for shareholders. In other words, although beta risk rises, this is coupled with negative returns. The time-varying Treynor ratios in Figure 4 and Table 9 provide qualitatively identical conclusions.

When we statistically test for differences in risk-adjusted returns between the non-recessionary and recessionary samples (the last column of Panel B in Table 8 and the last column in Table 9) we find that indeed risk-adjusted returns drop across all time windows following $\mathrm{T}_{0}$. These differences in samples are all significant at least at the $5 \%$ level and show that the positive risk-return tradeoff in the non-recessionary sample is actually inversed in the recessionary sample. 


\section{SUMMARY \& CONCLUDING REMARKS}

Debt issue announcements serve as a source of information for outside investors regarding the future earnings potential of an underlying firm. Since the Modigliani-Miller theorem on the irrelevancy of capital structure, there has been no agreement as to whether debt announcements are positively or negatively received by the market. Put another way, do they lead to rises or declines in shareholder wealth? Extant literature has produced mixed findings and cannot provide a conclusive answer to this question.

On the one hand, corporate finance theory posits that, consistent with the notion of market efficiency and that all market participants possess equal access to all relevant information, there should not be a sharp reaction to corporate disclosures such as debt announcements. In addition, the irrelevancy proposition argues that in perfect markets, it is of no consequence what capital structure a firm utilizes to fund its operations. Ross (1977) presents a signalling model whereby rises in leverage ought to be linked with a perception that the firm will rise in value. Since information asymmetry is an omnipresent force in the market, outside investors are tasked with the difficult responsibility of trying to 'decode' the true meaning of managerial disclosures. Ross (1977) argues that debt announcements do serve as a signal of value and that the underlying firm is committed to pursuing positive NPV projects. The empirical literature that follows Modigliani and Miller (1958) and Ross (1977) is mixed in terms of explaining how debt announcement signals have been received by the market.

We show that outside investors respond to debt announcement signals differently depending on aggregate economic conditions and sentiment. In an innovation relative to extant event study literature, we estimate time-varying betas, alphas and Treynor ratios to examine the risk-return tradeoff of announcing firms' common stock following debt announcements. We uncover the following regarding the market's reaction to debt announcements. Firstly, betas of announcing firms usually rise in varying degrees across time windows following the announcement of a new debt issue. Such rises are ostensibly more pronounced for firms that choose to make a debt announcement during recessionary times. Secondly, after estimating time-varying alphas and Treynor ratios, we find evidence of a positive risk-return tradeoff in the common stock of announcing firms that chose to make a debt announcement during normal economic conditions. Conversely, the risk-return tradeoff is negative for firms that make a debt announcement during recessionary periods when investor sentiment is low on aggregate.

The intuition behind these findings is as follows. Both in good and bad economic times, there is some degree of information asymmetry between inside managers and outside investors. During bad times, however, outside investors become more sensitized to this information asymmetry and more loss averse in response to the rising probability of losses on their portfolios. They have more of an inclination to question the quality and intent of an inside manager's decisions and announcement disclosures. An otherwise benign corporate announcement during a booming phase in the economy instead prompts questions and suspicions among investors. In the words of Akerlof (1970), they ask themselves whether the underlying firm is selling peaches or lemons? In other words, do corporate managers really have positive NPV projects to invest in? Or, will this new debt issue only raise the underlying firm's distress costs? 
In addition to their theoretical importance, our findings also carry cautionary messages for corporate managers. Specifically, if inside managers of a firm do have positive NPV projects to invest in and wish to signal this to outside investors, they need to be aware of the fact that the market can respond very differently to debt announcements based on aggregate market conditions. In other words, timing is everything from a managerial point of view. If inside managers choose to ignore this finding they may be sacrificing shareholder wealth along with possibly their own wealth (especially if their performance and compensation are a function of their firm's stock price performance). An otherwise positive signal can be interpreted negatively by the market if it is made at the wrong time.

\section{REFERENCES}

Abreu D, Brunnermeier MK (2002) Synchronization risk and delayed arbitrage. J Finan Econ 66:341-360. doi: 10.1016/S0304-405X(02)00227-1

Abreu D, Brunnermeier MK (2003) Bubbles and Crashes. Econometrica 71:173-204. doi:10.1111/1468$\underline{0262.00393}$

Akerlof GA (1970) The Market for "Lemons": Quality Uncertainty and the Market Mechanism. Quart J Econ 84:488500. doi:10.2307/1879431

Ammann M, Fehr M, Seiz R (2006) New evidence on the announcement effect of convertible and exchangeable bonds. J Multinat Finan Manage 16:43-63. doi:10.1016/j.mulfin.2005.03.001

Anderson MH, Prezas AP (2003) Asymmetric information, asset allocation, and debt financing. Rev Quant Finance Account 20:127-154. doi: 10.1023/A:1023094008710

Baker M, Wurgler J (2006) Investor sentiment and the cross-section of stock returns. J Finance 61:1645-1680. doi:10.1111/j.1540-6261.2006.00885.x 
Baker M, Wurgler J (2007) Investor sentiment in the stock market. J Econ Perspect 21:129-151. doi:10.1257/jep.21.2.129

Barberis N (2011) Psychology and the Financial Crisis of 2007-2008. Available at SSRN 1742463.

Berndt ER, Hall BH, Hall RE, Hausman JA (1974) Estimation and inference in nonlinear structural models. In: Annals of Economic and Social Measurement, Volume 3, number 4. NBER: 653-665

Bozos K, Nikolopoulos K, Ramgandhi G (2011) Dividend signaling under economic adversity: Evidence from the London Stock Exchange. Int Rev Finan Anal 20:364-374. doi:10.1016/i.irfa.2011.07.003

Brown NC, Christensen TE, Elliott WB, Mergenthaler RD (2012) Investor Sentiment and Pro Forma Earnings Disclosures. J Acc Res 50:1-40. doi:10.1111/i.1475-679X.2011.00427.x

Busenitz LW, Fiet JO, Moesel DD (2005) Signaling in Venture Capitalist-New Venture Team Funding Decisions: Does It Indicate Long-Term Venture Outcomes? Entrep Theory Pract 29:1-12. doi:10.1111/j.1540$\underline{6520.2005 .00066 . x}$

Caballero RJ, Krishnamurthy A (2008) Musical chairs: a comment on the credit crisis. Banque de France Financial Stability Review: Special Issue on Liquidity 11:9-11.

Carayannopoulos P, Nayak S (2013) Debt issuance under rule 144A and equity valuation effects. Rev Pac Basin Finan Mark Pol 16:1350007. doi: 10.1142/S0219091513500070

Charitou A, Lambertides N, Theodoulou G (2011) Dividend Increases and Initiations and Default Risk in Equity Returns. J Finan Quant Anal 46:1521-1543. doi:10.1017/S0022109011000305

Chen S-S, Ho KW, Lee C-F, Shrestha K (2004) Nonlinear models in corporate finance research: review, critique, and extensions. Rev Quant Finance Account 22:141-169. doi: 10.1023/B:REQU.0000015854.90533.be

Chen S-S, Su X-Q (2010) Market reaction to entry timing of corporate capital investment announcement: evidence from announcement-period abnormal returns and analysts' earnings forecast revisions. Rev Pac Basin Finan Mark Pol 13:495-515. doi: 10.1142/S0219091510002049

Connelly BL, Certo ST, Ireland RD, Reutzel CR (2011) Signaling Theory: A Review and Assessment. J Manage 37:39-67. doi:10.1177/0149206310388419

Cuthbertson K, Nitzsche D (2005) Quantitative financial economics: stocks, bonds and foreign exchange. John Wiley \& Sons,

Elitzur R, Gavious A (2003) Contracting, signaling, and moral hazard: a model of entrepreneurs, 'angels,' and venture capitalists. J Bus Venturing 18:709-725. doi:10.1016/S0883-9026(03)00027-2

Engle RF, Ng VK (1993) Time-Varying Volatility and the Dynamic Behavior of the Term Structure. J Money, Credit Bank 25:336-349. doi:10.2307/2077766

European Commission (2011). An information server on composite indicators and ranking systems, Accessed from http://composite-indicators.jrc.ec.europa.eu

Fama EF (1991) Efficient Capital Markets: II. J Finance 46:1575-1617. doi:10.1111/j.15406261.1991.tb04636.X

French KR, Schwert GW, Stambaugh RF (1987) Expected stock returns and volatility. J Finan Econ 19:3-29. doi:10.1016/0304-405X(87)90026-2

Friedman M (1953) The case for flexible exchange rates, (in Milton Friedman ed.), Essays in Positive Economics, University of Chicago Press, Chicago, IL.

Gangopadhyay P, Yook KC, Shin Y (2014) Insider trading and firm-specific return volatility. Rev Quant Finance Account 43:1-19. doi: 10.1007/s11156-013-0362-z

Glosten LR, Jagannathan R, Runkle DE (1993) On the Relation between the Expected Value and the Volatility of the Nominal Excess Return on Stocks. J Finance 48:1779-1801. doi:10.1111/j.15406261.1993.tb05128.x

Grullon G, Michaely R, Swaminathan B (2002) Are Dividend Changes a Sign of Firm Maturity? J Bus 75:387-424. doi: $10.1086 / 339889$

Lewis CM, Rogalski RJ, Seward JK (2001) The long-run performance of firms that issue convertible debt: an empirical analysis of operating characteristics and analyst forecasts. J Corp Financ 7:447-474. doi:10.1016/S0929-1199(01)00035-9 
Koutmos D (2012) An intertemporal capital asset pricing model with heterogeneous expectations. J Int Finan Markets, Inst Money 22:1176-1187. doi: 10.1016/j.intfin.2012.05.007

Koutmos D (2015) Is there a positive risk-return tradeoff? a forward-looking approach to measuring the equity premium. Europ Finan Manage 21:974-1013. doi: 10.1111/eufm.12043

Koutmos D (2016) Distilling private information from plain-vanilla options to predict future underlying stock price volatility: evidence from the H-shares of Chinese banks. Res Int Bus Financ 37:391-405. doi: 10.1016/j.ribaf.2016.01.017

Lewis CM, Rogalski RJ, Seward JK (2002) Risk changes around convertible debt offerings. J Corp Financ 8:6780. doi:10.1016/S0929-1199(01)00029-3

Madura J, Akhigbe A (1995) Influence of economic factors on the valuation effects of debt offerings. Appl Econ 27:907-915. doi:10.1080/00036849500000070

Masulis RW, Korwar AN (1986) Seasoned equity offerings. J Finan Econ 15:91-118. doi:10.1016/0304$\underline{405 X(86) 90051-6}$

McConnell JJ, Muscarella CJ (1985) Corporate capital expenditure decisions and the market value of the firm. J Finan Econ 14:399-422. doi:10.1016/0304-405X(85)90006-6

Mian GM, Srinivasan S (2012) Investor Sentiment and Stock Market Response to Earnings News. Acc Rev 87:1357-1384. doi:10.2308/accr-50158

Mikkelson WH, Partch MM (1986) Valuation effects of security offerings and the issuance process. J Finan Econ 15:31-60. doi:10.1016/0304-405X(86)90049-8

Milian JA (2016) Insider sales based on short-term earnings information. Rev Quant Finance Account 47:109128. doi: $10.1007 / \mathrm{s} 11156-014-0496-7$

Miller MH (1977) Debt and Taxes. J Finance 32:261-275. doi:10.1111/j.1540-6261.1977.tb03267.x

Modigliani F, Miller MH (1958) The Cost of Capital, Corporation Finance and the Theory of Investment. Amer Econ Rev 48:261-297.

Myers SC, Majluf NS (1984) Corporate financing and investment decisions when firms have information that investors do not have. J Finan Econ 13:187-221. doi:10.1016/0304-405X(84)90023-0

Nelson DB (1991) Conditional Heteroskedasticity in Asset Returns: A New Approach. Econometrica 59:347370. doi: $10.2307 / 2938260$

Pagan AR, Schwert GW (1990) Alternative models for conditional stock volatility. J Econometrics 45:267-290. doi:10.1016/0304-4076(90)90101-X

Patell JM (1976) Corporate Forecasts of Earnings Per Share and Stock Price Behavior: Empirical Test. J Acc Res 14:246-276. doi: $10.2307 / 2490543$

Ross SA (1973) The Economic Theory of Agency: The Principal's Problem. Amer Econ Rev 63:134-139.

Ross SA (1977) The Determination of Financial Structure: The Incentive-Signalling Approach. Bell J Econ 8:2340. doi: $10.2307 / 3003485$

Shaw KW (2012) CEO incentives and the cost of debt. Rev Quant Finance Account 38:323-346. doi: 10.1007/s11156-011-0230-7

Shleifer A, Vishny RW (1997) The Limits of Arbitrage. J Finance 52:35-55. doi:10.1111/j.15406261.1997.tb03807.x

Slovin MB, Sushka ME, Lai KWL (2000) Alternative flotation methods, adverse selection, and ownership structure: evidence from seasoned equity issuance in the U.K. J Finan Econ 57:157-190. doi:10.1016/S0304-405X(00)00054-4

Spence M (1973) Job Market Signaling. Quart J Econ 87:355-374. doi:10.2307/1882010

Spence M (2002) Signaling in Retrospect and the Informational Structure of Markets. Amer Econ Rev 92:434459. doi: $10.1257 / 00028280260136200$

Spiess DK, Affleck-Graves J (1999) The long-run performance of stock returns following debt offerings. J Finan Econ 54:45-73. doi:10.1016/S0304-405X(99)00031-8

Stiglitz JE (2000) The Contributions of the Economics of Information to Twentieth Century Economics. Quart J Econ 115:1441-1478. doi:10.1162/003355300555015 
Stiglitz JE (2002) Information and the Change in the Paradigm in Economics. Amer Econ Rev 92:460-501. doi: $10.1257 / 00028280260136363$

Strong N (1992) Modelling Abnormal Returns: A Review Article. J Bus Finan Account 19:533-553. doi:10.1111/j.1468-5957.1992.tb00643.x

Tversky A, Kahneman D (1992) Advances in prospect theory: Cumulative representation of uncertainty. J Risk Uncertainty 5:297-323. doi:10.1007/bf00122574

White H (1980) A Heteroskedasticity-Consistent Covariance Matrix Estimator and a Direct Test for Heteroskedasticity. Econometrica 48:817-838. doi:10.2307/1912934

Wu YL, Lee C-F (2008) Specification analysis of corporate equity financing decision: a conditional residual approach. Rev Quant Finance Account 31:395-423. doi: 10.1007/s11156-007-0083-2

Wurgler J, Zhuravskaya E (2002) Does Arbitrage Flatten Demand Curves for Stocks? J Bus 75:583-608. doi: $10.1086 / 341636$

Yen G, Lee, C-F (2008) Efficient market hypothesis (EMH): past, present and future. Rev Pac Basin Finan Mark Pol 11:305-329. doi: 10.1142/S0219091508001362

Zeidler F, Mietzner M, Schiereck D (2012) Risk dynamics surrounding the issuance of convertible bonds. J Corp Financ 18:273-290. doi:10.1016/i.jcorpfin.2011.12.001

Zhang Y, Wiersema MF (2009) Stock market reaction to CEO certification: the signaling role of CEO background. Strateg Manage J 30:693-710. doi: $10.1002 /$ smj.772 


\section{FIGURES \& TABLES}

Figure 1 Time-series plot of the FTSE 100 market price, economic sentiment and debt announcements

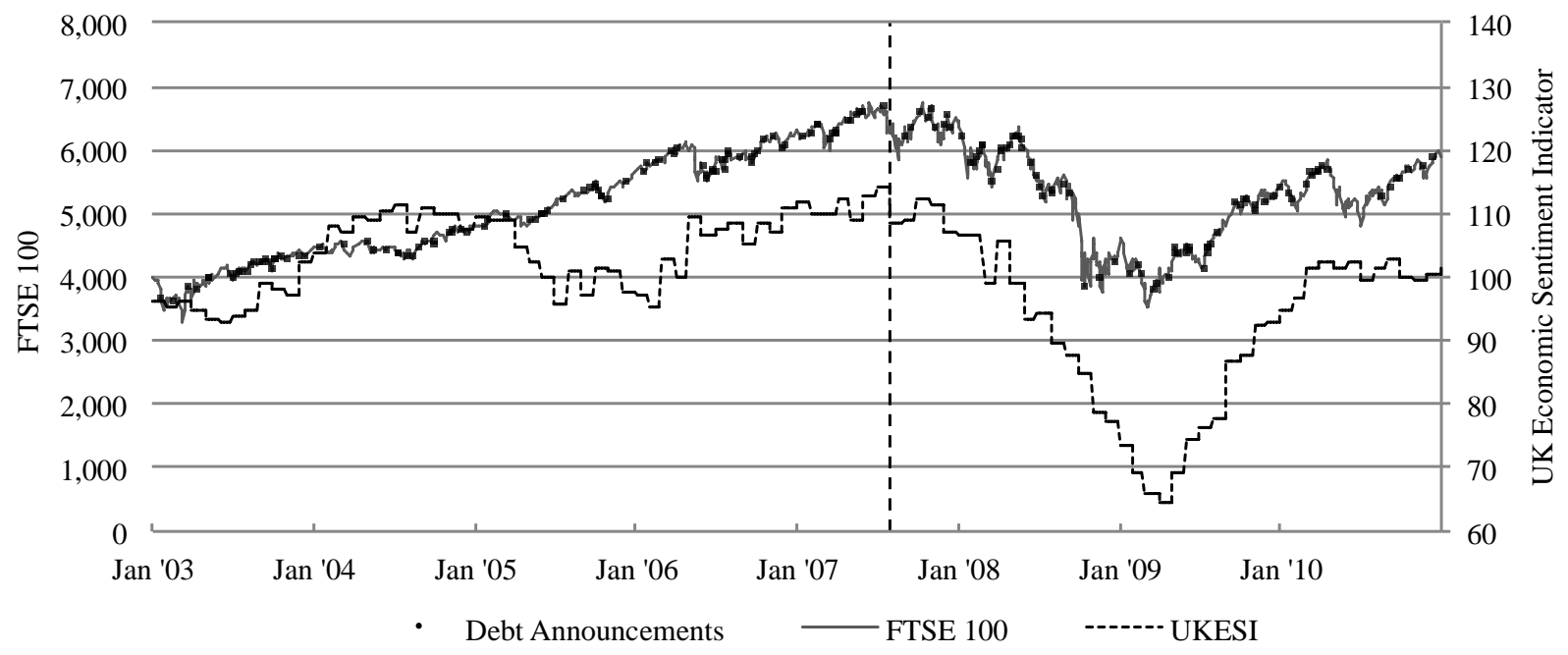


Figure 2: Mean time-varying betas around debt announcements

Panel A: Entire sample $(N=194)$

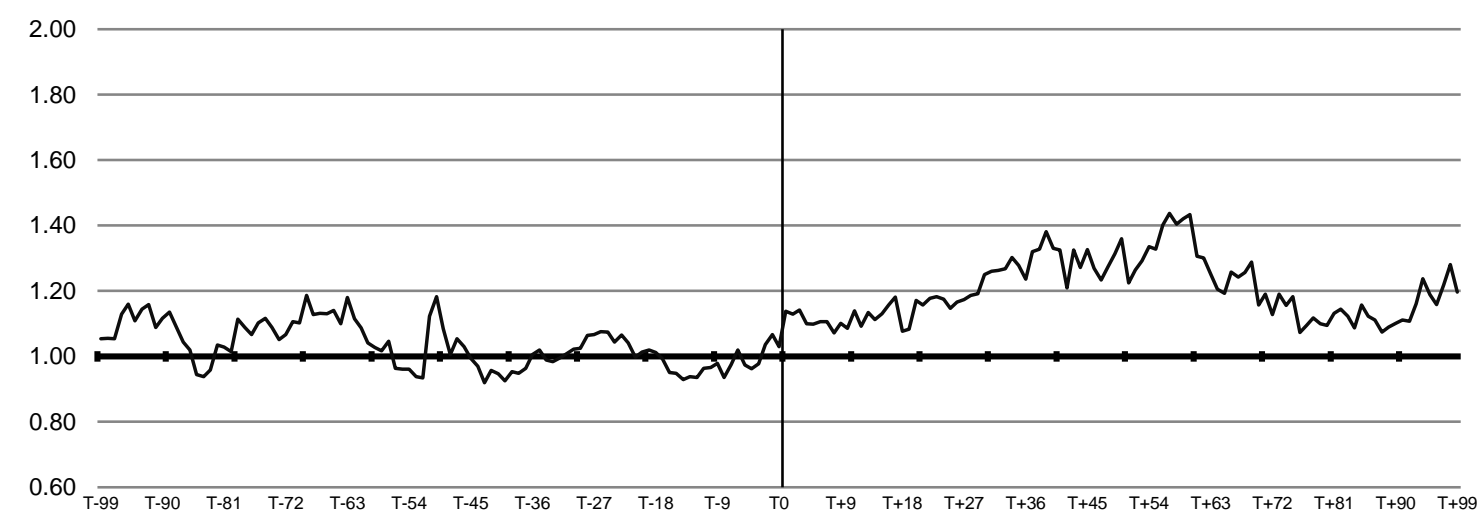

Panel B: Non-recessionary sub-sample $(N=109)$

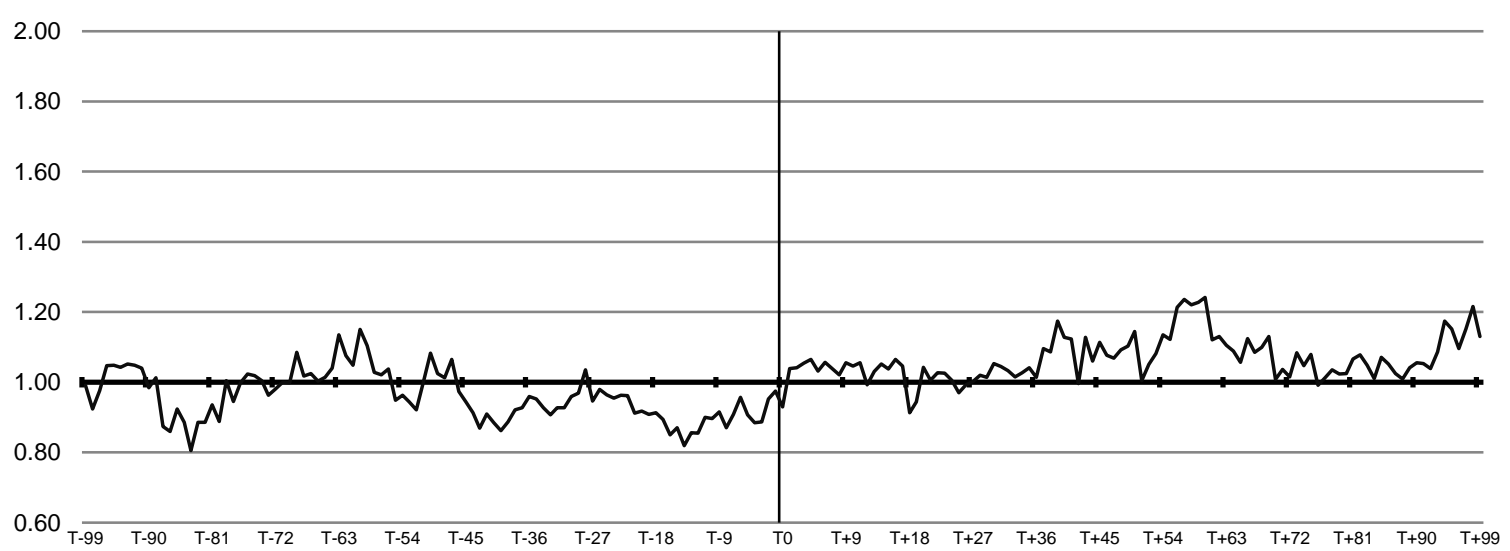

Panel C: Recessionary sub-sample $(N=85)$

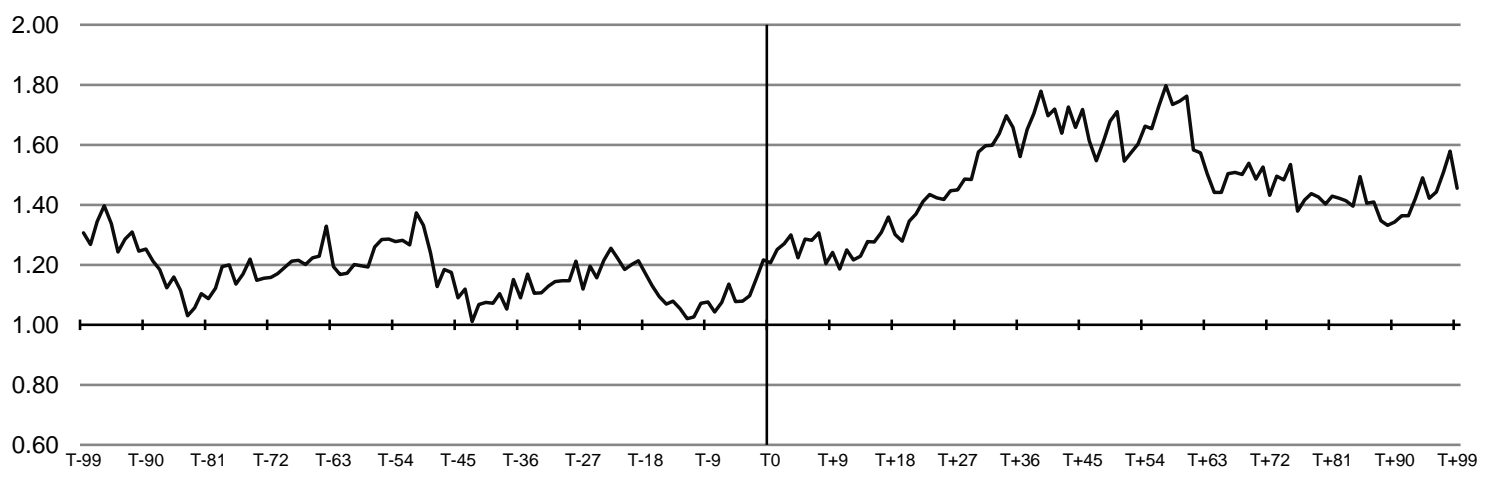


Figure 3: Mean cumulative time-varying alphas around debt announcements Panel A: Entire sample $(N=194)$

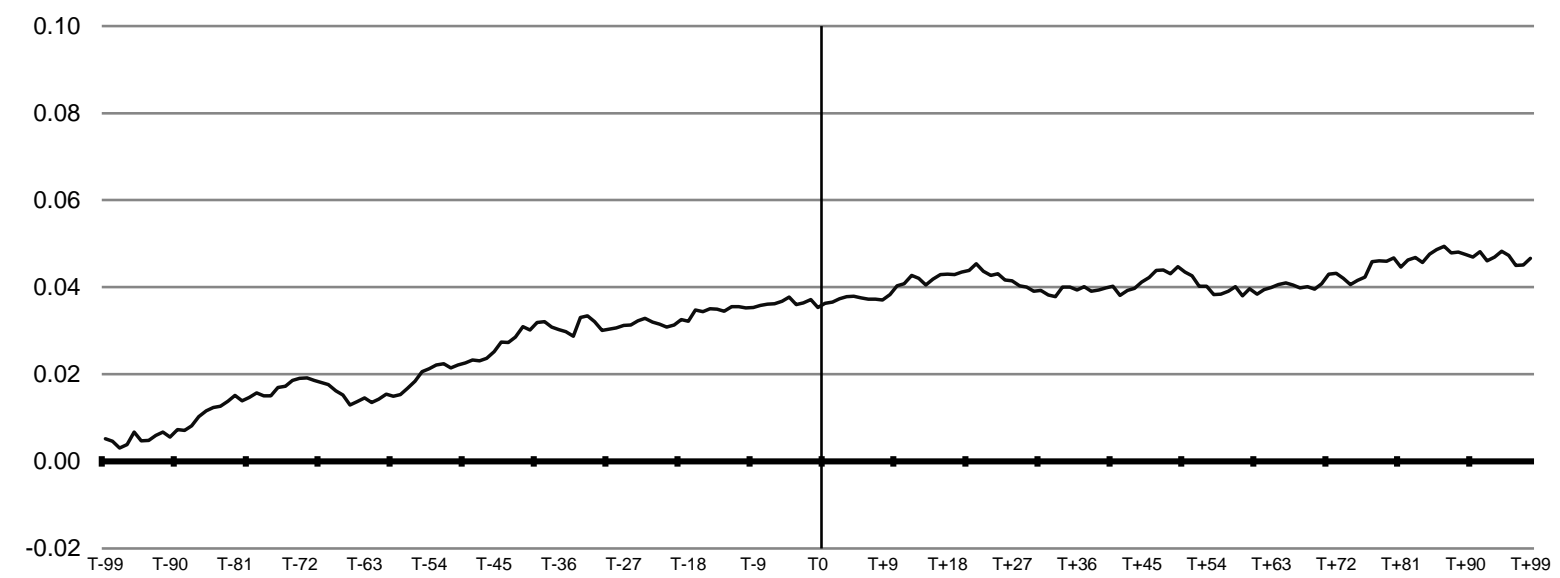

Panel B: Non-recessionary sub-sample $(N=109)$

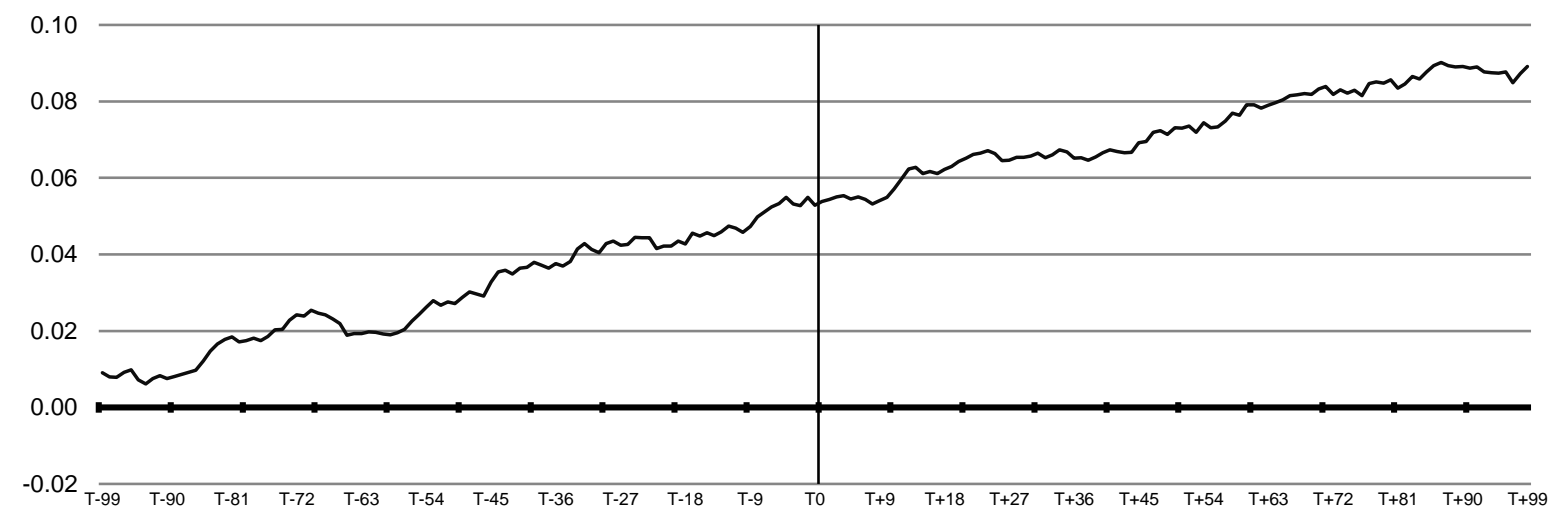

Panel C: Recessionary sub-sample $(N=85)$

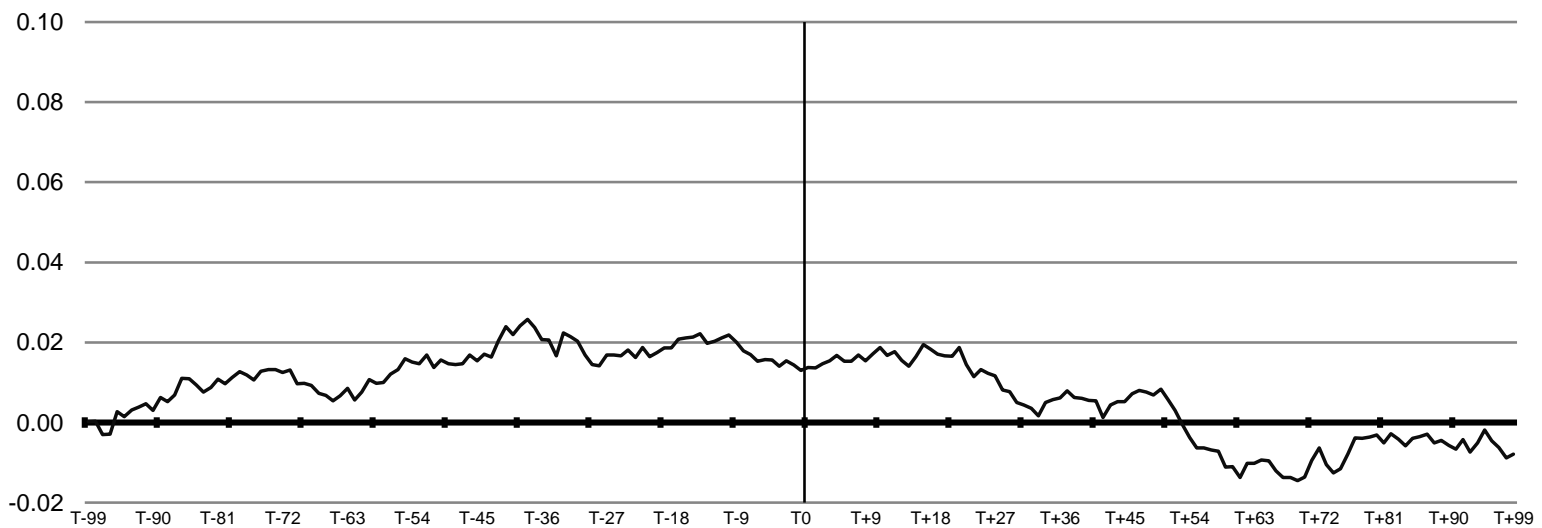


Figure 4: Time-varying Treynor ratios around debt announcements

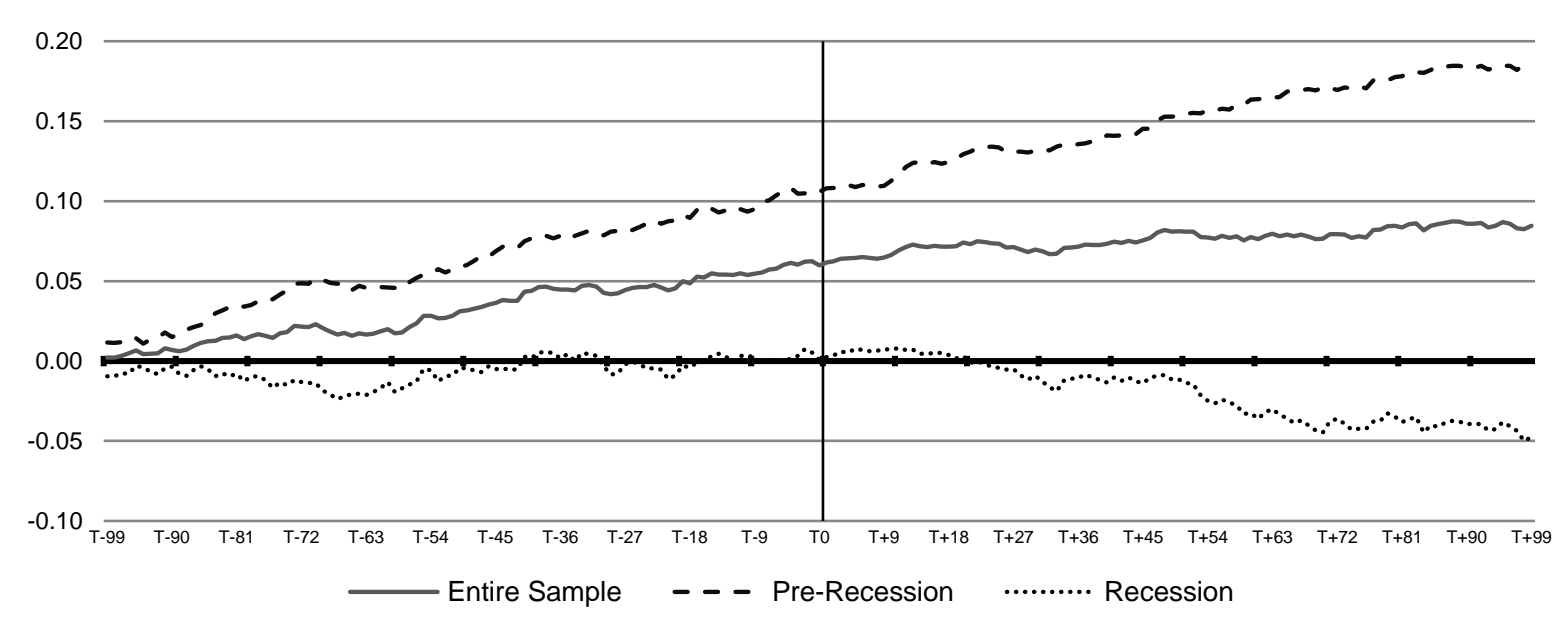


Table 1 Frequency of debt issues in the total sample $(\mathrm{N}=194)$

\begin{tabular}{ccrr}
\hline Year & Number of events & Debt value $(£$ mil $)$ & $\%$ \\
\hline 2003 & 27 & $12,500.0$ & $7.97 \%$ \\
2004 & 19 & $11,500.0$ & $7.33 \%$ \\
2005 & 20 & $9,420.0$ & $6.00 \%$ \\
2006 & 28 & $15,200.0$ & $9.69 \%$ \\
2007 & 25 & $14,100.0$ & $8.99 \%$ \\
2008 & 29 & $58,700.0$ & $37.41 \%$ \\
2009 & 29 & $18,400.0$ & $11.73 \%$ \\
2010 & 17 & $17,100.0$ & $10.90 \%$ \\
\hline Total & 194 & $156,920.0$ & $100 \%$ \\
\hline
\end{tabular}

Notes: This table reports the number of debt announcements for each fiscal year as well as their debt value (in millions of $€$ ). There are a total of 194 debt announcements whereby the largest percentage of such announcements took place in FY2008. 
Table 2 Average abnormal returns and average cumulative abnormal returns

\begin{tabular}{|c|c|c|c|}
\hline \multicolumn{4}{|c|}{ Panel A: Average abnormal returns (AAR) } \\
\hline Event day & AAR & ASAR & Sign test $(+) /(-)$ \\
\hline $\mathrm{T}-5$ & $\begin{array}{r}0.05 \% \\
(0.501)\end{array}$ & $\begin{array}{r}0.07 \\
{[0.747]}\end{array}$ & $\begin{array}{l}103 / 85 \\
{[0.135]}\end{array}$ \\
\hline $\mathrm{T}-4$ & $\begin{array}{l}0.08 \% \\
(0.62)\end{array}$ & $\begin{array}{r}0.05 \\
{[0.473]}\end{array}$ & $\begin{array}{r}100 / 86 \\
{[-0.292]}\end{array}$ \\
\hline $\mathrm{T}_{-3}$ & $\begin{array}{l}-0.22 \%^{* *} \\
(-1.924)\end{array}$ & $\begin{array}{c}-0.211^{* *} \\
{[-1.948]}\end{array}$ & $\begin{array}{l}84 / 105 \\
{[-2.567]}\end{array}$ \\
\hline $\mathrm{T}_{-2}$ & $\begin{array}{r}0.05 \% \\
(0.474)\end{array}$ & $\begin{array}{r}0.00 \\
{[0.010]}\end{array}$ & $\begin{array}{c}102 / 86 \\
{[-0.007]}\end{array}$ \\
\hline $\mathrm{T}_{-1}$ & $\begin{array}{r}-0.09 \% \\
(-0.888)\end{array}$ & $\begin{array}{c}-0.15 \text { ** } \\
{[-1.673]}\end{array}$ & $\begin{array}{l}87 / 102 \\
{[-2.140]}\end{array}$ \\
\hline $\mathrm{T}_{0}$ & $\begin{array}{l}-0.26 \%^{* * *} \\
(-2.352)\end{array}$ & $\begin{array}{c}-0.26^{* * *} \\
{[-2.446]}\end{array}$ & $\begin{array}{r}93 / 97 \\
{[-1.287]}\end{array}$ \\
\hline $\mathrm{T}_{+1}$ & $\begin{array}{r}0.07 \% \\
(0.764)\end{array}$ & $\begin{array}{r}0.06 \\
{[0.761]}\end{array}$ & $\begin{array}{c}102 / 82 \\
{[-0.007]}\end{array}$ \\
\hline $\mathrm{T}_{+2}$ & $\begin{array}{r}-0.01 \% \\
(-0.137)\end{array}$ & $\begin{array}{r}0.00 \\
{[-0.018]} \\
\end{array}$ & $\begin{array}{r}92 / 92 \\
{[-1.429]}\end{array}$ \\
\hline $\mathrm{T}_{+3}$ & $\begin{array}{r}0.07 \% \\
(0.664)\end{array}$ & $\begin{array}{r}0.04 \\
{[0.430]}\end{array}$ & $\begin{array}{c}101 / 83 \\
{[-0.150]}\end{array}$ \\
\hline $\mathrm{T}_{+4}$ & $\begin{array}{c}0.00 \% \\
(0.009)\end{array}$ & $\begin{array}{r}0.04 \\
{[0.461]}\end{array}$ & $\begin{array}{r}95 / 97 \\
{[-1.003]}\end{array}$ \\
\hline $\mathrm{T}_{+5}$ & $\begin{array}{r}0.00 \% \\
(0.037)\end{array}$ & $\begin{array}{r}-0.01 \\
{[-0.100]}\end{array}$ & $\begin{array}{l}107 / 82 \\
{[0.704]}\end{array}$ \\
\hline
\end{tabular}

Panel B: Average cumulative abnormal returns (ACAR)

\begin{tabular}{cccc}
\hline Event window & ACAR & ACSAR & Sign test $(+) /(-)$ \\
\hline $\mathrm{T}_{-1}, \mathrm{~T}_{+1}$ & $-0.28 \%^{* *}$ & $-0.31^{* * *}$ & $98 / 96$ \\
& $(-1.800)^{* * *}$ & {$[-2.368]^{* * *}$} & {$[-0.576]$} \\
$\mathrm{T}_{-1}, \mathrm{~T}_{0}$ & $-0.35 \%^{* * *}$ & $-0.37^{* * *}$ & $87 / 107$ \\
& $(-2.468)^{* *}$ & {$[-2.912]$} & {$[-2.140]$} \\
$\mathrm{T}_{0}, \mathrm{~T}_{+1}$ & $-0.19 \%^{*}$ & $-0.17^{*}$ & $94 / 100$ \\
& $(-1.394)$ & {$[-1.422]$} & {$[-1.145]$} \\
\hline
\end{tabular}

Notes: This table presents the average abnormal returns (AAR) and average standardized abnormal returns (ASAR) for the various event windows in panel A. In panel B we report the average cumulative abnormal returns (ACAR) and average cumulative standardized abnormal returns (ACSAR) for the respective event windows which reflect the immediate one-day reaction following the announcement date. The third column reports the sign test for panels A and B, respectively, and describes the distribution of positive $(+)$ versus negative $(-)$ returns as well as the z-statistic (McConnell and Muscarella, 1985).

The two-tail t-test results are presented in parentheses (.) and the Patell standardized residual (PSR) test results and sign test z-scores in brackets [.].

${ }^{*, * * * * *}$ denote significance at the $90.0 \%, 95.0 \%$ and $99.0 \%$ levels, respectively. 
Table 3 Average cumulative abnormal returns by economic conditions

\begin{tabular}{|c|c|c|c|}
\hline \multicolumn{4}{|c|}{ Panel A: ACAR by economic condition } \\
\hline Event window & RECESS $=0(N=109)$ & RECESS $=1(\mathrm{~N}=85)$ & Difference \\
\hline $\mathrm{T}_{-1}, \mathrm{~T}+1$ & $\begin{array}{r}-0.07 \% \\
(-0.389)\end{array}$ & $\begin{array}{c}-0.56 \%{ }^{* *} \\
(-1.975)\end{array}$ & $\begin{array}{r}-0.49 \% \\
{[-1.483]}\end{array}$ \\
\hline $\mathrm{T}_{-1}, \mathrm{~T}_{0}$ & $\begin{array}{r}-0.10 \% \\
(-0.649)\end{array}$ & $\begin{array}{l}-0.67 \% \\
(-2.624)\end{array}$ & $\begin{array}{l}-0.57 \%^{*} \\
{[-1.892]}\end{array}$ \\
\hline $\mathrm{T}_{0}, \mathrm{~T}_{+1}$ & $\begin{array}{r}-0.16 \% \\
(-1.131) \\
\end{array}$ & $\begin{array}{r}-0.24 \% \\
(-0.932)\end{array}$ & $\begin{array}{r}-0.08 \% \\
{[-0.029]}\end{array}$ \\
\hline \multicolumn{4}{|c|}{ Panel B: ACAR by UK economic sentiment indicator } \\
\hline Event Window & UKESI >100 $(\mathrm{N}=106)$ & UKESI <100 $(\mathrm{N}=88)$ & Difference \\
\hline $\mathrm{T}-1, \mathrm{~T}+1$ & $\begin{array}{r}0.01 \% \\
(0.058)\end{array}$ & $\begin{array}{l}-0.63 \%{ }^{* *} \\
(-2.370)\end{array}$ & $\begin{array}{c}-0.64 \%{ }^{* *} \\
{[-1.997]}\end{array}$ \\
\hline $\mathrm{T}_{-1}, \mathrm{~T}_{0}$ & $\begin{array}{c}-0.01 \% \\
(-0.037)\end{array}$ & $\begin{array}{l}-0.76 \% \\
(-3.055)\end{array}$ & $\begin{array}{l}-0.76 \%{ }^{* * *} \\
{[-2.587]}\end{array}$ \\
\hline $\mathrm{T}_{0}, \mathrm{~T}+1$ & $\begin{array}{r}0.02 \% \\
(0.096) \\
\end{array}$ & $\begin{array}{c}-0.45 \% \\
(-1.978)\end{array}$ & $\begin{array}{c}-0.47 \%{ }^{*} \\
{[-1.652]}\end{array}$ \\
\hline \multicolumn{4}{|c|}{$\begin{array}{l}\text { Notes: In panel A of this table we present the average cumulative abnormal returns (ACAR) for three event windows } \\
\text { surrounding the debt announcement date; the first column is for the sample period prior to the height of the recession } \\
\text { (from January } 1,2003 \text { until August } 9,2007 \text { ) while the second column is for the post-recessionary period (from August } 9 \text {, } \\
2007 \text { until December } 31,2010 \text { ). In the third column we compute whether there is a statistically significant difference in } \\
\text { ACAR between the first and second columns. Unlike in panel A, in panel B we divide the samples based on the level of the } \\
\text { UK Economic Sentiment Indicator (UKESI). When this indicator is greater than } 100 \text { (UKESI }>100 \text { ) it indicates a greater } \\
\text { possibility that market conditions are either positive or 'normal.' Conversely, when this indicator falls below } 100 \\
\text { (UKESI<100) it signals waning investor sentiment and possibly weak economic conditions. Finally, as in panel A, in the } \\
\text { third column of panel B we compute whether there is a statistically significant difference in ACAR between the first and } \\
\text { second columns. } \\
\text { The two-tail t-test results are presented in parentheses (.) and the z-test results in brackets [.]. } \\
*, * * * * * * \text { denote significance at the } 90.0 \%, 95.0 \% \text { and } 99.0 \% \text { levels, respectively. }\end{array}$} \\
\hline
\end{tabular}


Table 4 Descriptive statistics of all variables used in the analysis

Panel A: Correlation matrix of the variables in the cross sectional models

\begin{tabular}{|c|c|c|c|c|c|c|c|c|c|c|c|c|c|c|c|c|c|c|}
\hline & 1. & 2. & 3. & 4. & 5. & 6. & 7. & 8. & 9. & 10. & 11. & 12. & 13. & 14. & 15. & 16. & 17. & 18. \\
\hline 1. $\operatorname{CAR}(-1,0)$ & 1.00 & & & & & & & & & & & & & & & & & \\
\hline 2. LOGDEBT & 0.04 & 1.00 & & & & & & & & & & & & & & & & \\
\hline 3. EURO & -0.13 & 0.05 & 1.00 & & & & & & & & & & & & & & & \\
\hline 4. Private LoAN & 0.06 & $0.20^{* *}$ & -0.14 & 1.00 & & & & & & & & & & & & & & \\
\hline 5. STRAIGHT BOND & 0.03 & $-0.15^{*}$ & 0.13 & $-0.83^{* * *}$ & 1.00 & & & & & & & & & & & & & \\
\hline 6. CONVERT. Bond & $-0.15^{*}$ & -0.05 & -0.01 & -0.09 & $-0.48^{* * *}$ & 1.00 & & & & & & & & & & & & \\
\hline 7. USE OF FUNDS & 0.04 & 0.11 & 0.04 & 0.08 & -0.11 & 0.06 & 1.00 & & & & & & & & & & & \\
\hline 8. 1-OFf Issue & 0.04 & $-0.36^{* * *}$ & $0.31^{* * *}$ & $-0.36^{* * *}$ & $0.43^{* * *}$ & $-0.21^{* *}$ & $-0.17^{*}$ & 1.00 & & & & & & & & & & \\
\hline 9. $\%$ OF TA & -0.02 & $0.31^{* * *}$ & -0.11 & $0.33^{* * *}$ & $-0.31^{* * *}$ & 0.02 & 0.04 & $-0.25^{* * *}$ & 1.00 & & & & & & & & & \\
\hline 10. OPER. PROFIT & 0.00 & -0.10 & 0.11 & 0.04 & -0.04 & 0.01 & 0.07 & 0.10 & -0.13 & 1.00 & & & & & & & & \\
\hline 11. МтвV & -0.07 & -0.05 & $0.16^{*}$ & -0.03 & -0.14 & $0.29^{* * *}$ & $0.19^{* *}$ & -0.04 & -0.04 & -0.02 & 1.00 & & & & & & & \\
\hline 12. LTDTоTA & -0.03 & -0.12 & 0.10 & $0.22^{* *}$ & $-0.15^{*}$ & -0.07 & 0.01 & 0.03 & $0.25^{\text {*** }}$ & $0.20^{* *}$ & -0.14 & 1.00 & & & & & & \\
\hline 13. LOGAGE & -0.04 & $0.22^{* *}$ & -0.08 & 0.03 & 0.04 & -0.11 & 0.03 & $-0.31^{* * *}$ & -0.04 & -0.14 & -0.04 & $-0.21^{* *}$ & 1.00 & & & & & \\
\hline 14. RUNUP & $-0.21^{* *}$ & -0.09 & 0.05 & 0.12 & $-0.20^{* *}$ & $0.18^{*}$ & 0.09 & $-0.18^{*}$ & 0.03 & 0.01 & -0.04 & $0.15^{*}$ & -0.07 & 1.00 & & & & \\
\hline 15.30D MKT VoL. & -0.07 & 0.06 & 0.05 & -0.09 & $0.16^{*}$ & -0.13 & 0.00 & 0.13 & $-0.15^{*}$ & 0.01 & -0.05 & $-0.15^{*}$ & $0.20^{* *}$ & -0.14 & 1.00 & & & \\
\hline 16. TSPREADS $\%$ & $0.15^{*}$ & -0.01 & 0.06 & -0.12 & 0.12 & -0.03 & -0.01 & 0.09 & -0.05 & 0.06 & -0.01 & -0.01 & -0.03 & $-0.31^{* * *}$ & 0.04 & 1.00 & & \\
\hline 17. RECESS & $-0.15^{*}$ & $0.17^{*}$ & -0.06 & -0.02 & 0.11 & $-0.16^{*}$ & 0.03 & 0.09 & -0.07 & -0.05 & -0.09 & $-0.25^{* * *}$ & $0.32^{* * *}$ & $-0.16^{*}$ & $0.60^{* * *}$ & $-0.35^{* * *}$ & 1.00 & \\
\hline 18. UKESI (\%) & $0.17^{*}$ & -0.11 & 0.04 & 0.07 & -0.10 & 0.06 & $0.14^{*}$ & -0.05 & 0.06 & $0.15^{*}$ & 0.06 & $0.16^{*}$ & $-0.19^{* *}$ & 0.03 & $-0.29^{* * *}$ & $0.55^{* * *}$ & $-0.53^{* * *}$ & 1.00 \\
\hline
\end{tabular}
the variables in the cross sectional models

\begin{tabular}{|c|c|c|c|c|c|c|c|c|c|c|c|c|c|c|c|c|c|c|}
\hline & 1. & 2. & 3. & 4. & 5. & 6. & 7. & 8. & 9. & 10. & 11. & 12. & 13. & 14. & 15. & 16. & 17. & 18. \\
\hline Mean & -0.004 & 8.551 & 0.216 & 0.139 & 0.809 & 0.052 & 0.119 & 0.443 & 0.072 & 0.180 & 0.053 & 21.050 & 2.808 & 0.042 & 1.021 & -0.004 & 0.438 & 0.990 \\
\hline Std. Dev. & 0.020 & 0.521 & 0.413 & 0.347 & 0.394 & 0.222 & 0.324 & 0.498 & 0.177 & 0.182 & 0.468 & 15.852 & 1.166 & 0.175 & 0.591 & 0.010 & 0.497 & 0.113 \\
\hline Minimum & -0.073 & 6.720 & 0.000 & 0.000 & 0.000 & 0.000 & 0.000 & 0.000 & 0.000 & -2.000 & -1.668 & 0.000 & 0.693 & -0.643 & 0.271 & -0.026 & 0.000 & 0.644 \\
\hline Median & -0.002 & 8.600 & 0.000 & 0.000 & 1.000 & 0.000 & 0.000 & 0.000 & 0.029 & 0.194 & 0.025 & 20.947 & 2.708 & 0.037 & 0.828 & -0.001 & 0.000 & 1.008 \\
\hline Maximum & 0.051 & 10.650 & 1.000 & 1.000 & 1.000 & 1.000 & 1.000 & 1.000 & 1.546 & 0.469 & 6.073 & 71.622 & 4.812 & 0.863 & 4.716 & 0.013 & 1.000 & 1.128 \\
\hline
\end{tabular}

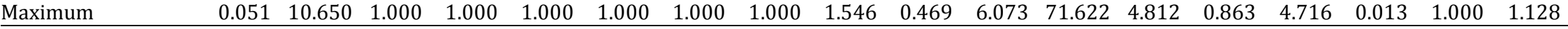

Notes: This table presents the correlation matrix (panel A) and summary statistics (panel B) of all the variables used in the cross sectional models. CAR(T-1,T0) measures the two day (T-1,T0) cumulative abnormal returns from the announcement of a new debt issue. LOGDEBT is the natural logarithm of the debt value to control for the size effect of equity issues on stock price movements; EURO is a dummy variable that equals 1 if the debt was issued in Euros and is 0 otherwise; PRIVATE LOAN is a dummy variable that equals 1 if debt was raised via some private arrangement or credit facilities and is 0 otherwise CONVERT.BOND is a dummy variable that equals 1 if the bond issue contains a convertibility option and is 0 otherwise. If a bond issue does not have a convertibility option, it is considered a straight bond. USE OF FUNDS is a dummy variable that takes the value of 1 if the debt was used for growth and is 0 for capital restructuring; 1-OFF ISSUE is a dummy variable that takes a value of 1 if the debt was a 'one-off issue and 0 otherwise; \%OFTA is the fraction of the debt value to total assets; OPER.PROFIT controls for operating firm profitability; MTBV is the market-to-book value of the underlying firm; LTDTOTA is longterm debt to total assets; LOGAGE measures, in log terms, the age of the firm; RUNUP is the cumulative share price return during the period (T-100, T-11) preceding the debt issue announcement; 30DMKTVOL is the realized 30-day volatility of the FTSE 100 index: TSPREADS\% is the spread between the 1-month and 30-year gilts; the dummy variable RECESS, which equals 0 for all announcements prior to August 9 , 2007 (N-109) and 1 for the following observations ( $N=85)$; and the UK Economic Sentiment Indicator ( UKES) which is disclosed on a monthly basis by the Directorate-General for Economic and Financial (

***,*** denote significance at the $90.0 \%, 95.0 \%$ and $99.0 \%$ levels, respectively. 
Table 5 Explaining abnormal returns

\begin{tabular}{|c|c|c|c|c|c|c|}
\hline & $\begin{array}{c}\text { Model } 1 \\
\text { Issue level }\end{array}$ & $\begin{array}{c}\text { Model } 2 \\
\text { Firm level }\end{array}$ & $\begin{array}{c}\text { Model } 3 \\
\text { Market } 1\end{array}$ & $\begin{array}{c}\text { Model } 4 \\
\text { Market } 2\end{array}$ & $\begin{array}{c}\text { Model } 5 \\
\text { Full } 1\end{array}$ & $\begin{array}{c}\text { Model } 6 \\
\text { Full } 2\end{array}$ \\
\hline INTERCEPT & $\begin{array}{c}-0.0229 \\
(-1.000)\end{array}$ & $\begin{array}{l}0.0005 \\
(0.125)\end{array}$ & $\begin{array}{l}0.0005 \\
(0.189)\end{array}$ & $\begin{array}{l}-0.0253 \\
(-1.631)\end{array}$ & $\begin{array}{c}-0.0234 \\
(-0.939)\end{array}$ & $\begin{array}{l}-0.0441 \\
(-1.401)\end{array}$ \\
\hline LOGDEBT & $\begin{array}{c}0.0022 \\
(0.850)\end{array}$ & - & - & - & $\begin{array}{l}0.0030 \\
(1.055)\end{array}$ & $\begin{array}{l}0.0025 \\
(0.876)\end{array}$ \\
\hline Euro & $\begin{array}{c}-0.0070^{* *} \\
(-2.158)\end{array}$ & - & - & - & $\begin{array}{c}-0.0066^{* *} \\
(-1.975)\end{array}$ & $\begin{array}{c}-0.0058^{*} \\
(-1.748)\end{array}$ \\
\hline PRIVATE LOAN & $\begin{array}{c}0.0024 \\
(0.626)\end{array}$ & - & - & - & $\begin{array}{c}0.0050 \\
(1.227)\end{array}$ & $\begin{array}{l}0.0039 \\
(0.947)\end{array}$ \\
\hline CONVERT. BOND & $\begin{array}{l}-0.0092 \\
(-1.572)\end{array}$ & - & - & - & $\begin{array}{l}-0.0080 \\
(-1.303)\end{array}$ & $\begin{array}{l}-0.0076 \\
(-1.225)\end{array}$ \\
\hline USE OF FUNDS & $\begin{array}{c}0.0034 \\
(0.874)\end{array}$ & - & - & - & $\begin{array}{c}0.0054 \\
(1.374)\end{array}$ & $\begin{array}{l}0.0033 \\
(0.835)\end{array}$ \\
\hline 1-OfF Issue & $\begin{array}{c}0.0043 \\
(1.382)\end{array}$ & - & - & - & $\begin{array}{c}0.0043 \\
(1.269)\end{array}$ & $\begin{array}{c}0.0030 \\
(0.884)\end{array}$ \\
\hline \%OFTA & - & $\begin{array}{l}-0.0015 \\
(-0.328)\end{array}$ & - & - & $\begin{array}{l}-0.0066 \\
(-0.828)\end{array}$ & $\begin{array}{l}-0.0076 \\
(-0.939)\end{array}$ \\
\hline OPER.PROFIT & - & $\begin{array}{l}-0.0005 \\
(-0.116)\end{array}$ & - & - & $\begin{array}{l}-0.0008 \\
(-0.111)\end{array}$ & $\begin{array}{l}-0.0027 \\
(-0.379)\end{array}$ \\
\hline MTвV & - & $\begin{array}{l}-0.0031^{*} \\
(-1.818)\end{array}$ & - & - & $\begin{array}{l}-0.0026 \\
(-0.902)\end{array}$ & $\begin{array}{l}-0.0021 \\
(-0.729)\end{array}$ \\
\hline LTDToTA & - & $\begin{array}{l}-0.0001 \\
(-0.687)\end{array}$ & - & - & $\begin{array}{l}-0.0001 \\
(-0.827)\end{array}$ & $\begin{array}{l}-0.0000 \\
(-0.440)\end{array}$ \\
\hline LoGAGE & - & $\begin{array}{l}-0.0008 \\
(-0.719)\end{array}$ & - & - & $\begin{array}{l}-0.0000 \\
(-0.004)\end{array}$ & $\begin{array}{l}-0.0006 \\
(-0.467)\end{array}$ \\
\hline RunUP & - & - & $\begin{array}{c}-0.0239^{\text {*** }} \\
(-3.126)\end{array}$ & $\begin{array}{c}-0.0227^{\text {*** }} \\
(-3.020)\end{array}$ & $\begin{array}{c}-0.0214^{\text {*** }} \\
(-2.685)\end{array}$ & $\begin{array}{c}-0.0192^{\text {** }} \\
(-2.406)\end{array}$ \\
\hline 30DMKTVoL. & - & - & $\begin{array}{l}0.0003 \\
(0.120)\end{array}$ & $\begin{array}{l}-0.0016 \\
(-0.720)\end{array}$ & $\begin{array}{c}0.0010 \\
(0.360)\end{array}$ & $\begin{array}{l}-0.0022 \\
(-0.944)\end{array}$ \\
\hline TSPREADS\% & - & - & $\begin{array}{c}0.0124 \\
(0.087)\end{array}$ & $\begin{array}{l}-0.0150 \\
(-0.096)\end{array}$ & $\begin{array}{l}-0.0266 \\
(-0.183)\end{array}$ & $\begin{array}{l}0.0046 \\
(0.029)\end{array}$ \\
\hline RECESS & - & - & $\begin{array}{l}-0.0067^{*} \\
(-1.863)\end{array}$ & - & $\begin{array}{c}-0.0101^{* *} \\
(-2.590)\end{array}$ & - \\
\hline UKESI (\%) & - & - & & $\begin{array}{c}0.0249 * \\
(1.742)\end{array}$ & - & $\begin{array}{c}0.0259^{*} \\
(1.712)\end{array}$ \\
\hline $\bar{F}$ & 1.697 & 0.749 & 4.126 & 4.010 & 2.034 & 1.750 \\
\hline R-squared & $5.20 \%$ & $1.00 \%$ & $8.00 \%$ & $7.80 \%$ & $14.60 \%$ & $12.90 \%$ \\
\hline Adj. R-squared & $2.10 \%$ & $-1.60 \%$ & $6.10 \%$ & $5.90 \%$ & $7.40 \%$ & $5.50 \%$ \\
\hline Sample Size & 194 & 194 & 194 & 194 & 194 & 194 \\
\hline
\end{tabular}

Notes: This table presents estimates for the coefficients from regression (6) with heteroskedastic consistent parameter estimates consistent with White (1980): CAR $\left(T_{-1}, T_{0}\right)=\alpha_{1}+\beta_{1}$ LOGDEBT $+\beta_{2}$ EURO $+\beta_{3}$ PRIVATELOAN $+\beta_{4}$ CONVERT.BOND $+\beta_{5}$ USE OF FUNDS $+\beta_{6} 1$-OFFISSUE $+\beta_{7} \%$ OFTA + $\beta_{8}$ OPER.PROFIT $+\beta_{9 M T B V}+\beta_{10 L T D T O T A}+\beta_{11}$ LOGAGE $+\beta_{12}$ RUNUP $+\beta_{13} 30 D M K T V O L+\beta_{14}$ TSPREADS $\%+\beta_{15}$ RECESS $+\beta_{16}$ UKESI $(\%)+\varepsilon$ t.

$\operatorname{CAR}\left(\mathrm{T}_{-1}, \mathrm{~T}_{0}\right)$ is the two day $\left(\mathrm{T}_{-1}, \mathrm{~T}_{0}\right)$ cumulative abnormal returns arising from the announcement of a new debt issue. LOGDEBTis the natural logarithm of the debt; EURO is a dummy variable that equals 1 if the debt was issued in Euros and is 0 otherwise; PRIVATELOANis a dummy variable that equals 1 if debt was raised via some private arrangement or credit facilities and is 0 otherwise; CONVERT.BOND is a dummy variable that equals 1 if the bond issue contains a convertibility option and is 0 otherwise. If a bond issue does not have a convertibility option, it is considered a straight bond. USE OF FUNDS is a dummy variable that takes the value of 1 if the debt was used for growth and is 0 for capital restructuring; 1-OFFISSUE is a dummy variable that takes a value of 1 if the debt was a 'one-off' issue and 0 otherwise; \%OFTA is the fraction of the debt value to total assets; OPER.PROFIT controls for operating firm profitability; MTBVis the market-to-book value of the underlying firm; LTDTOTAis long-term debt to total assets; LOGAGE measures, in log terms, the age of the firm; RUNUP is the cumulative share price return during the period (T-100, T-11) preceding the debt issue announcement; 3ODMKTVOL is the realized 30-day volatility of the FTSE 100 index; TSPREADS\% is the spread between the 1-month and 30-year gilts; the dummy variable RECESS, which equals 0 for all announcements prior to August 9, $2007(\mathrm{~N}=109)$ and 1 for the following observations $(\mathrm{N}=85)$; and the UK Economic Sentiment Indicator (UKESI). Two-tail t-test results are in parentheses (.)., ${ }^{* * * * * * *}$ denote significance at the $90.0 \%, 95.0 \%$ and $99.0 \%$ levels, respectively. 
Table 6 'Single-period' alphas and betas surrounding debt issue announcements

\begin{tabular}{|c|c|c|c|c|c|c|c|c|}
\hline & \multicolumn{2}{|c|}{ Full sample } & \multicolumn{2}{|c|}{$\begin{array}{c}\text { Non-recessionary } \\
\text { sub-sample }\end{array}$} & \multicolumn{2}{|c|}{$\begin{array}{c}\text { Recessionary } \\
\text { sub-sample }\end{array}$} & \multicolumn{2}{|c|}{$\begin{array}{c}\text { Differences } \\
\text { between sub-samples }\end{array}$} \\
\hline & Mean & Median & Mean & Median & Mean & Median & Mean & $\underline{\text { Median }}$ \\
\hline \multicolumn{9}{|l|}{ Alpha } \\
\hline$\alpha_{\mathrm{i}}($ alpha) & $0.0003^{* * *}$ & $0.0004^{* * *}$ & $0.0005^{*}$ & $0.0005^{*}$ & 0.0001 & 0.0001 & $-0.0004^{*}$ & $-0.0004^{*}$ \\
\hline$\alpha \Delta_{\mathrm{i}}(\Delta$ in alpha $)$ & $-0.0002^{*}$ & -0.0001 & -0.0001 & -0.0001 & $-0.0003^{*}$ & -0.0001 & $-0.0002^{*}$ & -0.0001 \\
\hline \multicolumn{9}{|l|}{ Market risk } \\
\hline$b_{i}$ (market beta) & $0.970^{* * *}$ & $0.864^{* * *}$ & $0.880^{* * *}$ & $0.848^{* * *}$ & $1.086^{* * *}$ & $0.942^{* * *}$ & $0.207^{* * *}$ & $0.094^{* *}$ \\
\hline $\mathrm{b} \Delta_{\mathrm{i}}(\Delta$ in market beta $)$ & 0.007 & 0.005 & -0.001 & -0.030 & $0.018^{* *}$ & $0.026^{* *}$ & $0.019^{* *}$ & $0.056^{* *}$ \\
\hline
\end{tabular}

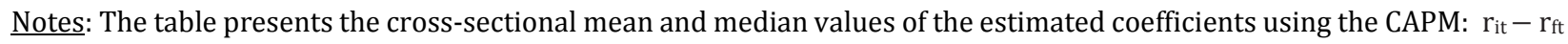
$=\mathrm{a}_{\mathrm{i}}+\mathrm{a} \Delta_{\mathrm{i}} \mathrm{D}_{\mathrm{t}}+\mathrm{b}_{\mathrm{i}}\left(\mathrm{r}_{\mathrm{mt}}-\mathrm{r}_{\mathrm{ft}}\right)+\mathrm{b} \Delta_{\mathrm{i}} \mathrm{D}\left(\mathrm{r}_{\mathrm{mt}}-\mathrm{r}_{\mathrm{ft}}\right)_{\mathrm{t}}+\varepsilon_{\mathrm{t}}$

The model is estimated from day $\mathrm{T}_{-} 99$ until day $\mathrm{T}_{+99}$ (201 daily observations) where $\mathrm{T}_{0}$ is the day when the debt issue announcement took place; $\mathrm{D}$ is a dummy variable that equals 1 for $\mathrm{t} \geq \mathrm{T}_{0}$ and 0 otherwise; $\mathrm{r}_{\mathrm{it}}$ is the daily return on stock $\mathrm{i}$; $\mathrm{r}_{\mathrm{ft}}$ is the monthly return on 1-month UK T-bills; $r_{m t}$ is the daily return on the FTSE 100 market index. Whereas the full sample consists of a total of 194 observations, the non-recessionary and recessionary sample consist of 109 and 85 observations, respectively. The significance levels of the means and medians are based on a 2-tailed t-test and a 2-tailed Wilcoxon rank test, respectively.

***,*** denote significance at the $90.0 \%, 95.0 \%$ and $99.0 \%$ levels, respectively. 
Table 7 Shifts in average stock betas around debt announcements

\begin{tabular}{|c|c|c|c|c|c|}
\hline Event window & Mean & Median & Maximum & Minimum & $\begin{array}{l}\text { Standard } \\
\text { deviation }\end{array}$ \\
\hline $\mathrm{T}_{-99}, \mathrm{~T}_{-49}$ & 1.0717 & 1.0883 & 1.1860 & 0.9345 & 0.0685 \\
\hline $\mathrm{T}-50, \mathrm{~T}_{-1}$ & 1.0002 & 0.9948 & 1.1821 & 0.9195 & 0.0521 \\
\hline $\mathrm{T}_{0}, \mathrm{~T}_{+5}$ & 1.1062 & 1.1146 & 1.1420 & 1.0300 & 0.0417 \\
\hline $\mathrm{T}_{+6}, \mathrm{~T}_{+30}$ & 1.1422 & 1.1466 & 1.2498 & 1.0714 & 0.0448 \\
\hline $\mathrm{T}+31, \mathrm{~T}+99$ & 1.2322 & 1.2400 & 1.4372 & 1.0727 & 0.0967 \\
\hline \multicolumn{6}{|c|}{ Panel B: Non-recessionary sample $(\mathrm{N}=109)$} \\
\hline Event window & Mean & Median & Maximum & Minimum & $\begin{array}{l}\text { Standard } \\
\text { deviation }\end{array}$ \\
\hline $\mathrm{T}-99, \mathrm{~T}-49$ & 0.9945 & 1.0049 & 1.1500 & 0.8053 & 0.0711 \\
\hline $\mathrm{T}_{-50}, \mathrm{~T}_{-1}$ & 0.9291 & 0.9197 & 1.0831 & 0.8190 & 0.0542 \\
\hline $\mathrm{T}_{0}, \mathrm{~T}_{+5}$ & 1.0269 & 1.0404 & 1.0649 & 0.9297 & 0.0491 \\
\hline $\mathrm{T}+6, \mathrm{~T}_{+30}$ & 1.0205 & 1.0272 & 1.0651 & 0.9130 & 0.0368 \\
\hline $\mathrm{T}_{+31}, \mathrm{~T}_{+99}$ & 1.0858 & 1.0784 & 1.2417 & 0.9919 & 0.0624 \\
\hline \multicolumn{6}{|c|}{ Panel C: Recessionary sample $(\mathrm{N}=85)$} \\
\hline Event window & Mean & Median & Maximum & Minimum & $\begin{array}{l}\text { Standard } \\
\text { deviation }\end{array}$ \\
\hline T-99, T-49 & 1.2168 & 1.2126 & 1.3975 & 1.0309 & 0.0794 \\
\hline $\mathrm{T}_{-50}, \mathrm{~T}_{-1}$ & 1.1294 & 1.1231 & 1.3309 & 1.0110 & 0.0674 \\
\hline $\mathrm{T}_{0}, \mathrm{~T}_{+5}$ & 1.2560 & 1.2605 & 1.2994 & 1.2060 & 0.0362 \\
\hline $\mathrm{T}+6, \mathrm{~T}+30$ & 1.3421 & 1.3079 & 1.5759 & 1.1853 & 0.1033 \\
\hline $\mathrm{T}_{+31}, \mathrm{~T}_{+99}$ & 1.5461 & 1.5369 & 1.7800 & 1.3315 & 0.1252 \\
\hline
\end{tabular}

Notes: This table shows the average changes in time-varying stock betas around new debt issue announcements for each of the respective time windows around the announcement date, $\mathrm{T}_{0}$. The betas are estimated for each observation from (9) using the dynamic bivariate EGARCH in (7) and (8), and then averaged in order to examine their overall behavior around debt announcement periods. The mean, median, maximum, minimum and standard deviation are reported for each of the respective time windows for the full sample (panel A), the non-recessionary sample (panel B), and the recessionary sample (panel C). Whereas the full sample consists of a total of 194 observations, the nonrecessionary and recessionary sample consist of 109 and 85 observations, respectively. 
Table 8 Time dummy regressions of beta and alpha around debt announcements

\begin{tabular}{|c|c|c|c|c|}
\hline & Full sample & $\begin{array}{l}\text { Non-recessionary } \\
\text { sub-sample }\end{array}$ & $\begin{array}{c}\text { Recessionary } \\
\text { sub-sample }\end{array}$ & $\begin{array}{c}\text { Differences } \\
\text { between sub-samples }\end{array}$ \\
\hline \multirow[t]{2}{*}{ INTERCEPT } & $\begin{array}{l}0.995^{* * *} \\
\left(17.942^{2}\right.\end{array}$ & $0.927^{* * *}$ & $1.137^{* * *}$ & $0.210^{* * *}$ \\
\hline & ) & $(17.701)$ & $(16.208)$ & $(9.785)$ \\
\hline $\mathrm{TD}(\mathrm{T}-99, \mathrm{~T}-51)$ & $\begin{array}{r}0.077 \\
(1.411)\end{array}$ & $\begin{array}{r}0.068 \\
(1.326)\end{array}$ & $\begin{array}{r}0.081 \\
(1.173)\end{array}$ & $\begin{array}{r}0.013 \\
(0.635)\end{array}$ \\
\hline $\mathrm{TD}\left(\mathrm{T}_{\left.-50, \mathrm{~T}_{-1}\right)}\right.$ & $\begin{array}{r}0.002 \\
(0.044)\end{array}$ & $\begin{array}{r}0.000 \\
(0.004)\end{array}$ & $\begin{array}{r}-0.010 \\
(0.151)\end{array}$ & $\begin{array}{r}-0.010 \\
(0.489)\end{array}$ \\
\hline $\mathrm{TD}\left(\mathrm{T}_{0}, \mathrm{~T}_{5}\right)$ & $\begin{array}{c}0.112^{*} \\
(1.935)\end{array}$ & $\begin{array}{l}0.100^{*} \\
(1.805)\end{array}$ & $\begin{array}{l}0.119^{*} \\
(1.671)\end{array}$ & $\begin{array}{r}0.019 \\
(0.724)\end{array}$ \\
\hline $\mathrm{TD}\left(\mathrm{T}_{6}, \mathrm{~T}_{30}\right)$ & $\begin{array}{l}0.138^{* *} \\
(2.419)\end{array}$ & $\begin{array}{r}0.088 \\
(1.614)\end{array}$ & $\begin{array}{l}0.189^{* *} \\
(2.590)\end{array}$ & $\begin{array}{l}0.102^{* * *} \\
(4.116)\end{array}$ \\
\hline $\mathrm{TD}\left(\mathrm{T}_{31}, \mathrm{~T}_{99}\right)$ & $\begin{array}{c}0.236^{* * *} \\
(4.183)\end{array}$ & $\begin{array}{l}0.158^{* * * *} \\
(2.974)\end{array}$ & $\begin{array}{l}0.407^{* * *} \\
(5.697)\end{array}$ & $\begin{array}{c}0.249^{* * *} \\
(10.950)\end{array}$ \\
\hline $\begin{array}{l}\mathrm{F} \\
\text { Adj. } \mathrm{R}^{2} \\
\end{array}$ & $\begin{array}{r}70.74 \\
62.0 \% \\
\end{array}$ & $\begin{array}{r}45.88 \\
51.1 \% \\
\end{array}$ & $\begin{array}{r}117.25 \\
76.3 \% \\
\end{array}$ & $\begin{array}{r}76.72 \\
63.8 \% \\
\end{array}$ \\
\hline \multicolumn{5}{|c|}{ Panel B: Dependent variable is time-varying alpha } \\
\hline & Full sample & $\begin{array}{c}\text { Non-recessionary } \\
\text { sub-sample }\end{array}$ & $\begin{array}{c}\text { Recessionary } \\
\text { sub-sample }\end{array}$ & $\begin{array}{c}\text { Differences } \\
\text { between sub-samples }\end{array}$ \\
\hline INTERCEPT & $\begin{array}{l}0.011 \text { ** } \\
(2.404)^{*}\end{array}$ & $\begin{array}{l}0.019^{* *} \\
(2.199)^{*}\end{array}$ & $\begin{array}{r}0.001 \\
(0.338)\end{array}$ & $\begin{array}{c}-0.019^{*} \\
(1.940)\end{array}$ \\
\hline $\mathrm{TD}\left(\mathrm{T}_{-99}, \mathrm{~T}_{-51}\right)$ & $\begin{array}{r}0.002 \\
(0.518)\end{array}$ & $\begin{array}{r}-0.002 \\
(0.226)\end{array}$ & $\begin{array}{l}0.008^{* * *} \\
(4.826)\end{array}$ & $\begin{array}{r}0.01 \\
(1.038)\end{array}$ \\
\hline $\mathrm{TD}\left(\mathrm{T}-50, \mathrm{~T}_{-1}\right)$ & $\begin{array}{l}0.021 \\
(4.546)\end{array}$ & $\begin{array}{l}0.023^{* * *} \\
(2.644)\end{array}$ & $\begin{array}{l}0.018^{* * *} \\
(11.457)^{-1}\end{array}$ & $\begin{array}{r}-0.005 \\
(0.530)\end{array}$ \\
\hline $\mathrm{TD}\left(\mathrm{T}_{0}, \mathrm{~T}_{5}\right)$ & $\begin{array}{l}0.026^{* * *} \\
(5.716)\end{array}$ & $\begin{array}{l}0.035^{* * *} \\
(4.085)\end{array}$ & $\begin{array}{l}0.014^{* * *} \\
(8.834)\end{array}$ & $\begin{array}{l}-0.021^{* *} \\
(2.229)\end{array}$ \\
\hline $\mathrm{TD}\left(\mathrm{T}_{6}, \mathrm{~T}_{30}\right)$ & $\begin{array}{l}0.030^{* * *} \\
(6.642)\end{array}$ & $\begin{array}{l}0.043^{* * *} \\
(4.920)\end{array}$ & $\begin{array}{l}0.014^{* * *} \\
(8.555)\end{array}$ & $\begin{array}{l}-0.028^{* * *} \\
(2.953)\end{array}$ \\
\hline $\mathrm{TD}\left(\mathrm{T}_{31}, \mathrm{~T}_{99}\right)$ & $\begin{array}{l}0.032^{* * *} \\
(6.954)\end{array}$ & $\begin{array}{l}0.059^{* * *} \\
(6.806)\end{array}$ & $\begin{array}{l}-0.004^{* *} \\
(2.133)\end{array}$ & $\begin{array}{l}-0.063^{* * *} \\
(6.492)\end{array}$ \\
\hline $\begin{array}{l}\text { F } \\
\text { Adj. } R^{2}\end{array}$ & $\begin{array}{l}261.66 \\
82.9 \%\end{array}$ & $\begin{array}{l}473.93 \\
84.9 \%\end{array}$ & $\begin{array}{l}131.85 \\
74.4 \%\end{array}$ & $\begin{array}{l}591.15 \\
84.6 \%\end{array}$ \\
\hline \multicolumn{5}{|c|}{$\begin{array}{l}\text { Ad]. } \\
\text { Notes: In panel A of this table, we report OLS regressions of average stock } \\
\text { EGARCH in (7) and (8) against time dummies (TD) for each of the respecti } \\
\text { date, } \mathrm{T}_{0} \text {. In panel B we do the same for firms' time-varying alphas as desc } \\
\text { returns. While the first column reports findings for the full sample, the sec } \\
\text { recessionary and recessionary sample periods, respectively. The last column } \\
\text { and recessionary sample periods. Whereas the full sample consists of a tota } \\
\text { and recessionary sample consist of } 109 \text { and } 85 \text { observations, respectively. } \\
\text { The two-tail t-test results are presented in parentheses (.). }\end{array}$} \\
\hline
\end{tabular}


Table 9 Time dummy regressions of Treynor ratios around debt announcements

\begin{tabular}{|c|c|c|c|c|}
\hline \multicolumn{5}{|c|}{ Dependent Variable: Treynor Ratios } \\
\hline & Full sample & $\begin{array}{l}\text { Non-recessionary } \\
\text { sub-sample }\end{array}$ & $\begin{array}{c}\text { Recessionary } \\
\text { sub-sample }\end{array}$ & $\begin{array}{c}\text { Differences } \\
\text { between sub-samples }\end{array}$ \\
\hline \multirow[t]{2}{*}{ INTERCEPT } & $0.016^{*}$ & $0.037^{* *}$ & $-0.011^{* *}$ & $-0.048^{* *}$ \\
\hline & $(1.838)$ & $(1.975)$ & $(2.387)$ & $(2.079)$ \\
\hline \multirow[t]{2}{*}{$\mathrm{TD}\left(\mathrm{T}_{-99,} \mathrm{~T}_{-51}\right)$} & -0.001 & -0.001 & 0.000 & 0.000 \\
\hline & $(0.073)$ & $(0.040)$ & $(0.099)$ & $(0.012)$ \\
\hline \multirow[t]{2}{*}{$\mathrm{TD}\left(\mathrm{T}-50, \mathrm{~T}_{-1}\right)$} & $0.032^{* * *}$ & $0.048^{* *}$ & $0.011^{* *}$ & -0.038 \\
\hline & $(3.689)$ & $(2.582)$ & $(2.218)$ & $(1.625)$ \\
\hline \multirow[t]{2}{*}{$\mathrm{TD}\left(\mathrm{T}_{0}, \mathrm{~T}_{5}\right)$} & $0.047^{* * *}$ & $0.072^{* * *}$ & $0.016^{* * *}$ & $-0.056^{* *}$ \\
\hline & $(5.516)$ & $(3.860)$ & $(3.235)$ & $(2.431)$ \\
\hline \multirow[t]{2}{*}{$\mathrm{TD}\left(\mathrm{T}_{6}, \mathrm{~T}_{30}\right)$} & $0.055^{* * *}$ & $0.088^{* * *}$ & $0.013^{* *}$ & $-0.075^{* * *}$ \\
\hline & $(6.418)$ & $(4.705)$ & $(2.585)$ & $(3.234)$ \\
\hline \multirow[t]{2}{*}{$\mathrm{TD}\left(\mathrm{T}_{31}, \mathrm{~T}_{99}\right)$} & $0.063^{* * *}$ & $0.127^{* * *}$ & $-0.018^{* * *}$ & $-0.144^{* * *}$ \\
\hline & $(7.428)$ & $(6.775)$ & $(3.523)$ & $(6.176)$ \\
\hline $\mathrm{F}$ & 639.70 & 416.97 & 93.38 & 240.07 \\
\hline Adj. $R^{2}$ & $87.7 \%$ & $84.7 \%$ & $62.7 \%$ & $80.3 \%$ \\
\hline
\end{tabular}

Notes: In this table, we report OLS regressions of average time-varying Treynor ratios estimated from (12) against time dummies (TD) for each of the respective time windows around the announcement date, $\mathrm{T}_{0}$. While the first column reports findings for the full sample, the second and third columns report for the non-recessionary and recessionary sample periods, respectively. The last column reports differences in the non-recessionary and recessionary sample periods. Whereas the full sample consists of a total of 194 observations, the non-recessionary and recessionary sample consist of 109 and 85 observations, respectively.

The two-tail t-test results are presented in parentheses (.).

$*, * *, * * *$ denote significance at the $90.0 \%, 95.0 \%$ and $99.0 \%$ levels, respectively. 